\title{
DIREITOS DE POVOS INDÍGENAS NO BRASIL: O “NÚCLEO ESSENCIAL DE DIREITOS” ENTRE DIVERSIDADE E INTEGRACIONISMO
}

\author{
RIGHTS OF INDIGENOUS PEOPLES IN BRAZIL: \\ THE “ESSENTIAL CORE OF RIGHTS” BETWEEN DIVERSITY AND \\ INTEGRATIONISM
}

\section{DERECHOS DE LOS PUEBLOS INDÍGENAS EN BRASIL: EL “NUCLEO ESENCIAL DE DERECHOS” ENTRE DIVERSIDAD E INTEGRACIONISMO}

\author{
Milena Petters Melo \\ https://orcid.org/0000-0001-5044-2382 / http://lattes.cnpq.br/3171293357004052 / mpettersmelo@gmail.com \\ Universidade Regional de Blumenau - FURB \\ Blumenau, SC, Brasil.
}

THIAGO RAFAEL BURCKHART

https://orcid.org/0000-0001-5483-9336 / http://lattes.cnpq.br/9528776774218197 / thiago--rafa@hotmail.com Universidade Regional de Blumenau - FURB Blumenau, SC, Brasil.

\begin{abstract}
RESUMO
Este trabalho objetiva analisar os direitos de povos indígenas no Brasil, focalizando a construção teórica de um núcleo essencial destes direitos no paradigma da diversidade cultural e o impacto da tese do marco temporal nesta estrutura normativa. A pesquisa bibliográfica e de documentos é complementada com inserções no estudo da jurisprudência. A perspectiva metodológica parte da teoria da constituição e da análise sociológica do direito em chave dialógica e crítica. A conclusão segue no sentido de afirmar que a tese do marco temporal, por envolver uma interpretação restritiva de diretos, aponta para a permanência de práticas integracionistas e coloca-se como um concreto impedimento à concretização do núcleo essencial de direitos de povos indígenas, ao reconhecimento material da diversidade cultural e à dinâmica intercultural do Estado Democrático de Direito.
\end{abstract}

Palavras-chave: Direitos de Povos Indígenas; Núcleo Essencial de Direitos; Diversidade; Integracionismo; Brasil.

\begin{abstract}
This paper aims to analyze the rights of indigenous peoples in Brazil, focusing on the theoretical construction of the "essential core of rights" in the paradigm of cultural diversity and the impact of the recent "marco temporal" thesis on this normative framework. The bibliographical and documental research is complemented with a jurisprudence study. The methodological perspective is grounded in constitutional theory and sociological analysis of law, in a dialogical and critical approach. The conclusion affirms that the "marco temporal" thesis, understood as a restrictive interpretation of rights, is a concrete impediment to cultural diversity, to the construction of the multicultural and intercultural State and the concretizaion of the essential core of rights of indigenous peoples.
\end{abstract}

Keywords: Rights of Indigenouse Peoples; Essential Core of Rights; Diversity; Integrationism; Brazil. 


\section{RESUMEN}

Este trabajo tiene por objetivo analizar los derechos de los pueblos indígenas en Brasil, centrándose en la construcción teórica del "núcleo esencial de derechos" en el paradigma de la diversidad cultural y el impacto de la tesis del "marco temporal" en esta estructura normativa. La investigacion bibliografica y de documientos es complementada con la insercion en estudios jurisprudenciales. La perspectiva metodologica se inscribe en la teoria constitucional y analisis sociologico del derecho en llave dialogica dialogica y critica. La conclusión establece que la tesis del "marco temporal", como una interpretación restrictiva de derechos, es un impedimento concreto para el reconocimiento de la diversidad cultural, la construcción del estado multicultural e intercultural y la realización del núcleo esencial de derechos de los pueblos indígenas.

Palabras clave: Derechos de Pueblos Indígenas; Nucleo Esencial de Derechos; Diversidad; Integracionismo; Brasil.

\section{SUMÁRIO}

INTRODUÇAO; 10 NÚCLEO ESSENCIAL DE DIREITOS INDÍGENAS; 2 O PARADIGMA DA DIVERSIDADE E A SUPERAÇÃO DO INTEGRACIONISMO HISTÓRICO; 3 A TESE DO MARCO TEMPORAL E A PERMANÊNCIA DO INTEGRACIONISMO; CONCLUSÃO; REFERÊNCIAS.

\section{INTRODUÇÃO}

A segunda metade do século XX ficou conhecida como a era dos direitos, a partir da definição utilizada por Norberto Bobbio para designar o fortalecimento da proteção dos direitos fundamentais e dos direitos humanos no plano constitucional e internacional. Ao mesmo tempo, o diálogo entre estes dois planos impulsionou a conformação de um sistema de proteção de direitos em diferentes níveis. Neste contexto, os movimentos constitucionais “democratizantes da democracia" e o incremento do sistema internacional de proteção de direitos humanos permitiram a expansão e especialização deste sistema, que passou a salvaguardar o patrimônio cultural da humanidade na sua diversidade, bem como sujeitos e bens com proteção especial em função das suas particularidades. O paulatino e recente processo de abertura política e reconhecimento jurídico de novos sujeitos e novos direitos, inscritos e positivados a partir de um novo contexto sociopolítico, também consente conceber teoricamente o nascimento de um “paradigma da diversidade cultural”, grifo nosso, ou mesmo uma era da diversidade. Os povos indígenas de diferentes nacionalidades encontram-se na centralidade deste amplo processo. Como parte integrante de uma comunhão nacional, mas que busca afirmação da sua própria heterogeneidade sociocultural, os povos indígenas passaram a mobilizar-se cultural e politicamente a fim de projetar juridicamente suas reivindicações na direção do multiculturalismo e da interculturalidade. 
ISSN 1981-3694

(DOI): $10.5902 / 1981369439249$

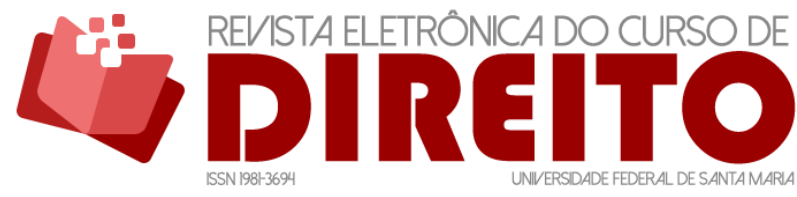

DIREITOS DE POVOS INDÍGENAS NO BRASIL: O “NÚCLEO ESSENCIAL DE DIREITOS” ENTRE DIVERSIDADE E INTEGRACIONISMO

MILENA PETTERS MELO THIAGO RAFAEL BURCKHART

As recentes evoluções aquisitivas do constitucionalismo contemporâneo latinoamericano bem como do direito internacional dos direitos humanos, que se colocam como contribuições profícuas para a compreensão de um patrimônio comum do constitucionalismo democrático, estabelecem uma nova realidade jurídica para os povos indígenas. Em compasso com a proteção da diversidade cultural, do multiculturalismo e da interculturalidade, estas evoluções implicam a superação formal do integracionismo histórico que marcou presença nas práticas jurídicas e políticas em grande parte do continente latinoamericano.

A projeção normativa dos direitos indígenas na Constituição de 1988 e nos tratados e convenções internacionais que tratam desta matéria dão base para a concepção teórica da estrutura de um "núcleo essencial de direitos de povos indígenas", grifo nosso, que funciona como bloco de constitucionalidade e de convencionalidade para os atos normativos e políticas públicas, colmando-se nas demandas socioculturais destes povos no domínio de suas vidas cotidianas.

Esta evolução normativa, entretanto, convive com as contradições e paradoxos da práxis jurídica e política. Efetivamente, a proteção dos direitos indígenas no Brasil se embate em interesses de cunho político-econômicos de grande escala. Assim, perpetua-se a questão indígena, especialmente no que toca a reivindicação pela demarcação de terras indígenas.

De fato, a tese do marco temporal, emersa no Supremo Tribunal Federal no caso Raposa/Serra do Sol em 2009, que obsta a garantia do direito à terra a povos indígenas que nelas não se encontravam na data de promulgação da Constituição de 1988, passou a ser instrumentalizada pelo Judiciário para impedir, em última instância, o exercício de um direito constitucionalmente afirmado. Desde sua criação no referido caso, esta tese se posiciona na centralidade do debate contemporâneo sobre os direitos de povos indígenas no Brasil.

Nesse sentido, o presente artigo tem por objetivo analisar o problema da proteção dos direitos de povos indígenas no Brasil, focalizando a construção teórica de um "núcleo essencial de direitos" no paradigma da diversidade cultural e o impacto da tese do marco temporal nesta estrutura normativa. Parte de duas hipóteses interligadas que seguem no sentido de afirmar que: 1. Da análise da ordem constitucional brasileira em diálogo com a proteção internacional dos direitos humanos deflui um núcleo essencial de direitos dos povos indígenas; 2. As práticas jurídico-políticas que subvertem esta ordem normativa representam, na prática, a permanência do modelo do integracionismo histórico. A pesquisa bibliográfica e de documentos é complementada com inserções no estudo da jurisprudência. A perspectiva metodológica parte da teoria da constituição e da análise sociológica do direito em chave dialógica e crítica. 0 artigo 
divide-se em três partes: I - O núcleo essencial de direitos ; II - 0 paradigma da diversidade e a superação formal do integracionismo histórico; III - A tese do marco temporal e a permanência do integracionismo.

\section{NÚCLEO ESSENCIAL DE DIREITOS}

Nas décadas de 1970 e 1980 o paulatino engajamento político-cultural dos povos indígenas ganhou corpo através de um empoderamento político ${ }^{1}$, em grande parte da América Latina. A partir da reapropriação dos conceitos de cultura ${ }^{2}$, etnicidade e indigenismo, em um processo mais amplo de politização da cultura $^{3}$ e, consequentemente, de sua projeção na arena política e na esfera jurídica ${ }^{4}$, os povos indígenas passaram a organizar-se social e politicamente como sujeitos políticos e sujeitos de direitos para fundar um novo indigenismo ${ }^{5}$. Neste período observa-se o "renascer dos povos indígenas para o direito", grifo nosso, seja do ponto de vista do direito interno dos Estados latino-americanos, seja na esfera do direito internacional dos direitos humanos e de seu engajamento político nas instâncias representativas em ambos os contextos.

No Brasil, com a Constituição de 1988, a constitucionalização dos direitos indígenas posicionou estes direitos em uma nova gramática de leitura jurídica. Os direitos indígenas

\footnotetext{
1 Para uma análise do processo de "empoderamento político" dos povos indígenas no Brasil, ver: SOUZA FILHO, Carlos Frederico Marés de. Multiculturalismo e direitos indígenas. In: SANTOS, Boaventura de Sousa (Org.). Reconhecer para libertar: os caminhos do cosmopolitismo cultural. Rio de Janeiro: Civilização Brasileira, 2003. Mais especificamente sobre o empoderamento político e comunicativo como base do desenvolvimento alternativo, ver: FRIEDMANN, John. Empowerment. The Politics of Alternative Development. Oxford: Blackwell, 1992.

2 Como aponta: CUNHA, Manuela Carneiro da. Cultura com aspas e outros ensaios. São Paulo: Cosac Naufy, 2009.

${ }^{3}$ Partindo da teoria politica e da cultura, Seyla Benhabib aponta que esse processo marca a estrutura das sociedades ocidentais a partir da década de 1970, no qual as pautas por reconhecimento derivantes da intensificaçao da relações interculturais passam a ganhar relevância. Para aprofundamentos, ver: BENHABIB, Seyla. Las reivindicaciones de la cultura: igualdad y diversidade en la era global. Traducido por Alejandra Vassallo. Buenos Aires: Katz, 2006.

${ }^{4}$ Em chave crítica, o filosofo indiano Homi Bhabha sustenta que o empoderamento político de grupos e povos até então marginalizados política e culturalmente, dentre eles os povos autoctones, ampliam a "promessa de justiça" e o repertório jurídico capaz de tutelá-lo, ou seja, a configuração de "novos direitos". Cfe. BHABHA, Homi. Nuevas minorias, nuevos derechos: notas sobre cosmopolitismos vernáculos. Buenos Aires: Siglo XXI, 2013.

${ }^{5}$ Para compreender o conceito de indigenismo e suas repercussões políticas, ver: RAMOS, Alcida Rita. Indigenism: ethnic politics in Brazil. Madinson : University of Wisconsin Press, 1998; NIEZEN, Ronald. The origins of indigenism: human rights and the politics of identity. Berkeley : University of California Press, 2003.
} 
ISSN 1981-3694

(DOI): $10.5902 / 1981369439249$

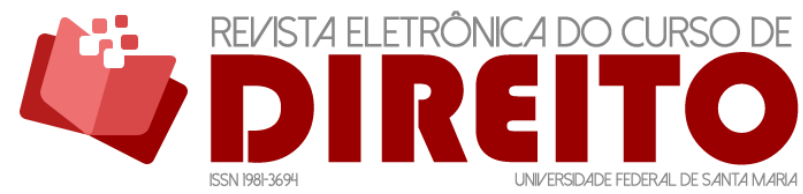

DIREITOS DE POVOS INDÍGENAS NO BRASIL: O “NÚCLEO ESSENCIAL DE DIREITOS" ENTRE DIVERSIDADE E INTEGRACIONISMO

MILENA PETTERS MELO THIAGO RAFAEL BURCKHART

passaram a se associar aos princípios e direitos fundamentais constitucionalmente protegidos, sendo reforçados pelo diálogo com o plano internacional de proteção dos direitos humanos, propiciado pelas cláusulas de abertura dos parágrafos do artigo 50 da Constituição.

Com um capítulo específico dedicado aos índios ${ }^{6}$, garantindo a proteção e ao reconhecimento do valor da sua organização social, de suas práticas culturais e específicas cosmovisões, as predisposições constitucionais abriram espaço, ao menos do ponto de vista formal-normativo e teórico-constitucional, para a superação do integracionismo histórico vigente no país desde o início do século $X X^{7}$.

A regulação jurídica da questão indígena no âmbito desta nova forma jurídica protegida constitucionalmente passa, então, a exigir do Estado e das políticas institucionais respostas efetivas às demandas por reconhecimento ${ }^{8}$, especialmente no que se refere à proteção das específicas identidades na diversidade cultural do Estado-nação' É nesse sentido que a Constituição de 1988 se converteu em uma espécie de símbolo para o movimento indigenista e para os povos indígenas, ancoradouro de algumas de suas demandas históricas.

O texto constitucional de 1988 foi resultado de um amplo engajamento político tanto dos povos indígenas quanto de instituições indigenistas ao longo da Assembleia Nacional Constituinte de 1987-1988. No período anterior, a experiência histórica da ditadura militar foi responsável por violações sistemáticas dos direitos de povos indígenas no país. Neste período atrocidades foram perpetradas como crimes de Estado, são exemplos: o genocídio do povo Waimiri-Atroari, no Amazonas ${ }^{10}$; o genocídio dos Avá-Canoeiro no Araguaia e os sucessivos massacres dos Cinta Larga no Mato Grosso ${ }^{11}$; o bombardeio de tribos pelas Forças Armadas com uso de Napalm² ${ }^{12}$ Além da escravização, criação de cadeias clandestinas, proibição de falar a

\footnotetext{
${ }^{6}$ Capítulo VIII “Dos Índios”, do Título VIII “Da Ordem Social”.

${ }^{7}$ Quando foi criado o Serviço Nacional de Proteção do Índio.

8 Para uma análise teórica e filosófica sobre a "teoria do reconhecimento" que focaliza a dimensão jurídica como uma de suas dimensões centrais, ver: HONNETH, Axel. Luta por reconhecimento: a gramática moral dos conflitos sociais. São Paulo : Editora 34, 2003.

9 Como aponta Roque de Barros Laraia, se até então a diversidade era um problema que estava para além do Estado-nação, inscrito nos povos "diferentes" que configuram a dinâmica política de outros países, a partir de então a diversidade passa a tornar-se um problema interno. LARAIA, Roque de Barros. Cultura: um conceito antropológico. Rio de Janeiro : Jorge Zahar, 2001.

10 Conforme relatado pelo COMITÉ ESTADUAL DA VERDADE DO AMAZONAS. 0 genocídio do Povo WaimirAtroari. Manaus, 2012, p. 158. Disponível em: http://www.dhnet.org.br/verdade/resistencia/a_pdf/r_cv_am_waimiri_atroari.pdf. Acesso em: 23 ago. 2020.

11 BRASIL. COMISSÃO NACIONAL DA VERDADE (CNV). Relatório. Brasília, 2014, p. 201. Disponível em: http://cnv.memoriasreveladas.gov.br/. Acesso em: 23 ago. 2020

12 SÃO PAULO. COMISSÃO DA VERDADE DO ESTADO DE SÃO PAULO “RUBENS PAIVA". Relatório. Capítulo Violações aos direitos dos povos indígenas. 2015, p. 3233.
} 
ISSN 1981-3694

(DOI): 10.5902/1981369439249

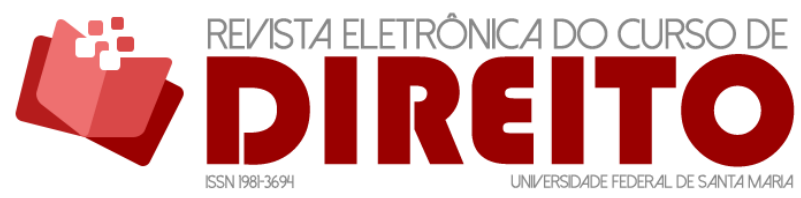

DIREITOS DE POVOS INDÍGENAS NO BRASIL: O “NÚCLEO ESSENCIAL DE DIREITOS" ENTRE DIVERSIDADE E INTEGRACIONISMO

MILENA PETTERS MELO THIAGO RAFAEL BURCKHART

própria língua, estabelecimento de critérios de indianidade, tentativa de emancipação de povos indígenas, conferimento de certidões negativas da existência desses povos para o licenciamento ilegal de atividades econômicas em suas terras ${ }^{13}$, dentre outros. Nesse contexto, a oportunidade de refundar a ordem constitucional mobilizou os interesses e as reivindicações dos povos indígenas e das instituições que thes apoiam politicamente.

$\mathrm{Na}$ esfera internacional a década de 1980 também constituiu um momento político favorável ao reconhecimento da diversidade cultural e dos direitos de povos indígenas. A Comissão de Direitos Humanos da Organização das Nações Unidas (ONU) conduziu a instituição, em 1982, do Grupo de Trabalho sobre as Populações Indígenas. O trabalho deste Grupo que foi protagonizado por líderes indígenas resultou na revisão de instrumentos jurídicos internacionais, como a Convenção n. 107 da Organização Internacional do Trabalho (OIT) sobre os Direitos de Povos Indígenas e Tribais, de 1957, um documento de viés integracionista ${ }^{14}$. Seguindo em outra direção, em 1989 foi aprovada a Convenção n. 169 da OIT, que rearticulou a abordagem jurídica de uma série de direitos internacionalmente reconhecidos aos povos indígenas, inclusive reconhecendo novos direitos e enfatizando a sua participação ativa na tomada de decisões, como é o caso da previsão de consulta aos povos indígenas ${ }^{15}$. Observa-se, assim, a reinvenção do direito internacional para os povos indígenas, também dimensionado em uma nova gramática jurídica $^{16}$.

Atualmente, as evoluções aquisitivas do constitucionalismo contemporâneo e do sistema internacional de proteção dos direitos demonstram o vicejar de um renascimento dos povos indígenas para o direito ${ }^{17}$. Os direitos constitucionalmente protegidos e a abertura constitucional à proteção dos direitos humanos plasmam-se em bases sólidas para a (re)construção de uma nova política indigenista pluralista no Brasil.

${ }^{13}$ Cfe. FERNANDES, Pádua. Povos indígenas, segurança nacional e a Assembleia Nacional Constituinte. Revista Insurgência, Brasília, v. 1, n. 2, 2015, p. 145-146.

${ }^{14} \mathrm{Cfe}$. ANAYA, S. James. Los pueblos indígenas en el derecho internacional. Trad. Luis Rodríguez-Piñero Royo. Madrid: Editorial Trotta, 2005, p. 90; NIEZEN, Ronald. Public Justice and the Anthropology of Law. Cambridge: Cambridge University Press, 2010, p. 118.

15 “Artigo $6^{\circ}, 1$. Ao aplicar as disposições da presente Convenção, os governos deverão: a) consultar os povos interessados, mediante procedimentos apropriados e, particularmente, através de suas instituições representativas, cada vez que sejam previstas medidas legislativas ou administrativas suscetíveis de afetálos diretamente".

${ }^{16}$ Para uma análise sobre o redimensionamento dos direitos de povos indígenas na América Latina, com enfoque no direito internacional e comparado, ver: STAVENHAGEN, Rodolfo. Los pueblos originários: el debate necesario. Buenos Aires : CLACSO, 2010.

${ }^{17}$ Conforme a tese de Carlos Frederico Marés Souza Filho. Para aprofundamentos, ver: SOUZA FILHO, Carlos Frederico Marés. 0 renascer dos povos indígenas para o direito. Curitiba : Juruá, 1998. 
ISSN 1981-3694

(DOI): 10.5902/1981369439249

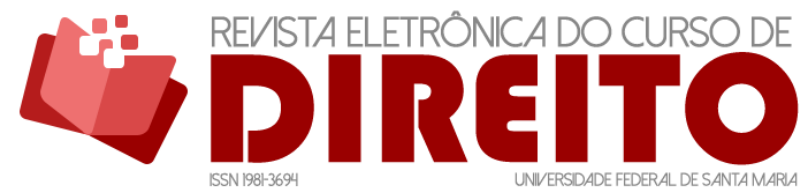

DIREITOS DE POVOS INDÍGENAS NO BRASIL: O “NÚCLEO ESSENCIAL DE DIREITOS" ENTRE DIVERSIDADE E INTEGRACIONISMO

MILENA PETTERS MELO THIAGO RAFAEL BURCKHART

Neste contexto, em termos teóricos e no plano formal da normatividade, uma análise jurídica dos documentos permitem arquitetar a ideia de um "núcleo essencial de direitos de povos indígenas", grifo nosso. Este núcleo pode ser compreendido como um conjunto de direitos constitucional e internacionalmente reconhecidos aos povos indígenas, que podem assumir a titularidade individual, coletiva ou difusa, e que dão sustentação para o controle de constitucionalidade e de convencionalidade de atos normativos. Além de funcionar como diretriz para a tomada de decisões e organização de iniciativas, projetos e programas voltados a atender as necessidades humanas concretas nas especificidades socioculturais destes povos, na esfera de suas vidas cotidianas.

O núcleo é constituído por direitos específicos e gerais de povos indígenas reconhecidos pelo Estado brasileiro, abrindo espaço também para a tutela do direito de cada povo a partir do reconhecimento de suas multifacetadas práticas culturais. Ao se delimitar no âmbito constitucional e internacional, este núcleo é composto por direitos fundamentais e direitos humanos de povos indígenas. Assim, o núcleo essencial de direitos de povos indígenas afirma o grau de fundamentalidade ${ }^{18}$ dos direitos indígenas reconhecidos em instrumentos nacionais e internacionais, a partir da constatação normativa de que os direitos fundamentais podem ser identificados fora do catálogo específico da Constituição Federal ${ }^{19}$.

Da análise sistemática da Constituição de 1988 e dos documentos internacionais, podese compreender o núcleo essencial de direitos de povos indígenas estruturado em três pilares.

No primeiro pilar encontram-se os direitos territoriais e ambientais. Estes direitos conformam uma unidade em razão de não poderem ser compreendidos separadamente, na medida em que, para os povos indígenas, a terra e a proteção do meio ambiente estão intimamente relacionadas. A natureza é um espaço sagrado. A terra é a base para a vida e, portanto, para a sobrevivência da comunidade.

No segundo pilar, o direito à autodeterminação dos povos indígenas, ou, como afirma Rodolfo Stavenhagen, o etnodesenvolvimento ${ }^{20}$, que se relaciona com a capacidade de autogestão e autogoverno de suas tribos e comunidades.

\footnotetext{
18 Para aprofundamentos sobre o conceito de "direito fundamental", ver: FERRAJOLLI, Luigi. Por uma teoria do direito e dos bens fundamentais. Porto Alegre : Livraria do Advogado, 2011.

19 CANOTILHO, José Joaquim Gomes. Direito Constitucional e Teoria da Constituição. Coimbra : Almedina, 2012.

20 STAVENHAGEN, Rodolfo. Etnodesenvolvimento: uma dimensão ignorada no pensamento desenvolvimentista. Anuário Antropológico, vol 84, 1985, p. 11-44.
} 
ISSN 1981-3694

(DOI): 10.5902/1981369439249

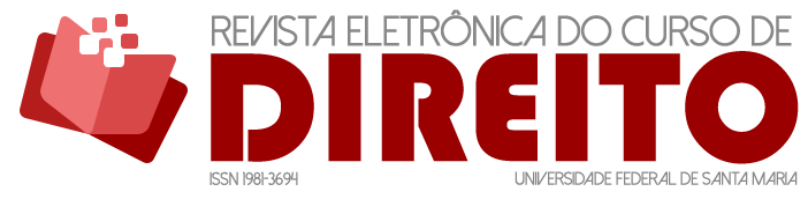

DIREITOS DE POVOS INDÍGENAS NO BRASIL: O “NÚCLEO ESSENCIAL DE DIREITOS” ENTRE DIVERSIDADE E INTEGRACIONISMO

MILENA PETTERS MELO THIAGO RAFAEL BURCKHART

No terceiro pilar, os direitos culturais de povos indígenas, que reconhecem sua autonomia cultural, suas epistemologias, suas nacionalidades, suas crenças, tradições e artefatos culturais.

Os direitos territoriais estiveram na centralidade da questão indígena e ainda marcam grande parte das reivindicações desses povos. Do ponto de vista constitucional, o direito à terra e ao meio ambiente ecologicamente equilibrado estão garantidos respectivamente nos artigos 231, § $1^{\circ}$ e 225 da Constituição de $1988^{21}$. 0 artigo 231, $\S 1^{\circ}$, enfatiza que as terras tradicionalmente ocupadas pelos índios são todas aquelas habitadas em caráter permanente, as utilizadas para suas atividades produtivas, as imprescindíveis à preservação dos recursos ambientais necessários ao seu bem-estar e à sua reprodução física e cultural. 0 que demonstra a intrínseca relação entre os direitos territoriais, a proteção ambiental e a salvaguarda da organização sociocultural indígena.

0 artigo que trata do meio ambiente aponta que todos possuem direito ao meio ambiente ecologicamente equilibrado, considerado bem de uso comum do povo, inscrito na dinâmica de proteção intergeracional.

No âmbito da proteção internacional ${ }^{22}$, a Convenção 169 da OIT faz uma série de referências ao direito à terra de povos indígenas. Esta Convenção aponta a necessidade dos governos adotarem medidas em cooperação com os povos indígenas para proteger e preservar o meio ambiente e os territórios dos povos indígenas (art. 7, 4). Dedicando uma parte específica para tratar das terras indígenas, esta Convenção enfatiza que a interpretação do conceito terras indígenas deve compreender de modo amplo o território, abrangendo a totalidade do habitat das regiões que os povos indígenas ocupam ou utilizam de alguma forma. Dentre outros pontos, a Convenção 169 da OIT reconhece o direito de posse e propriedade ${ }^{23}$ para os povos indígenas (art. $14,1)$, determina a proteção dos recursos naturais existentes em suas terras (art. 15, 1), além de impedir que os povos indígenas sejam transladados das terras que ocupam, exceto nos casos que contem com o consentimento expresso das comunidades $(16,1)$.

Ainda no direito internacional, a Declaração Internacional sobre os Direitos de Povos Indígenas de 2007 também estabelece que os povos indígenas possuem direito às suas terras, territórios e recursos que possuem e ocupam tradicionalmente ou que tenham utilizado e

21 Para melhor compreensão da dogmática jurídica sobre o direito à terra de povos indígenas, ver: BARBOSA, Marco Antonio. Direito antropológico e terras indígenas no Brasil. São Paulo : Plêiade, 2001.

${ }^{22}$ Para uma melhor compreensão sobre o direito à terra de povos indígenas no âmbito internacional, ver: GILBERT, Jérémie. Direito à terra como direito humano: argumentos em prol de um direito específico à terra. Revista Internacional de Direitos Humanos, ed. 18, 2013.

${ }^{23} \mathrm{Na}$ legislação brasileira, contudo, somente se reconhece o direito à posse. 
ISSN 1981-3694

(DOI): $10.5902 / 1981369439249$

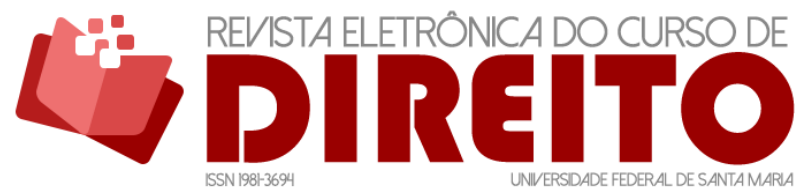

DIREITOS DE POVOS INDÍGENAS NO BRASIL: O “NÚCLEO ESSENCIAL DE DIREITOS" ENTRE DIVERSIDADE E INTEGRACIONISMO

MILENA PETTERS MELO THIAGO RAFAEL BURCKHART

adquirido $(26,1)$, além do controle de suas terras, territórios e recursos $(26,2)$, destaca o dever do Estado de assegurar esse direito por meio da demarcação $(26,3)$, e também ressalta que os povos indígenas não serão removidos à força de suas terras (artigo 10). Além disso, reconhece que os povos indígenas tem direito à conservação e proteção do meio ambiente e da capacidade produtiva de suas terras, territórios e recursos (art. 29, 1). Neste documento, os direitos territoriais e ambientais encontram-se relacionados com o direito à alimentação, à água, dentre outros direitos que garantam a vida destes povos em seus respectivos territórios.

O direito à autodeterminação dos povos indígenas não é expressamente previsto no capítulo específico dedicado aos índios na Constituição Federal de 1988. No entanto, um dos princípios fundamentais das relações internacionais que se destaca logo no início do texto constitucional, em seu artigo $4^{\circ}$, inciso III, consagra a autodeterminação dos povos. Considerando a fundamentalidade deste princípio e a compreensão sistemática da Constituição, voltada à uma sociedade plural e solidária, seria plausível em uma interpretação extensiva do dispositivo, conceber a autodeterminação como um princípio aplicável aos povos indígenas ${ }^{24}$.

Essa compreensão também pode defluir de um monismo internacionalista dialógico ${ }^{25}$, visto que os tratados internacionais são mais enfáticos com relação à previsão deste direito e também de seu conteúdo. Neste contexto, a autodeterminação dos povos indígenas não se associa com a possibilidade de criação de um novo Estado, mas relaciona-se com maiores e melhores espaços de autonomia e auto-governo dentro do Estado plural.

A Declaração Internacional sobre os Direitos de Povos Indígenas estabelece em seu artigo 3 o direito dos povos indígenas à autodeterminação, que se consubstancia na capacidade de determinarem livremente sua condição política e buscar livremente o seu desenvolvimento econômico, social e cultural. 0 artigo 4 estabelece que o exercício do direito à autodeterminação compreende a autonomia ou autogoverno nas questões relacionadas a seus assuntos internos e locais, assim como os meios para disporem dos meios para financiar suas funções autônomas. De acordo com a Declaração, o direito à autodeterminação também compreende a capacidade de conservar e reforçar suas próprias instituições políticas, jurídicas, econômicas, sociais e culturais, mantendo ao mesmo tempo o direito de participar plenamente,

\footnotetext{
${ }^{24}$ Para aprofundamentos, ver: BARBOSA, Marco Antônio. Autodeterminação: direito à diferença. São Paulo: Plêiade, 2011.

${ }^{25}$ Nesse sentido, a solução monista para o problema das relações entre o Direito Internacional dos Direitos Humanos com o Direito interno envolve o diálogo entre as fontes, ao fim de que se aplique a norma mais favorável, "essa 'melhor norma' há de ser encontrada à luz da dimensão material ou substancial das fontes de proteção em jogo, prevalecendo a que maior peso protetivo tiver em determinado caso concreto. MAZZZUOLI, Valerio de Oliveira. Curso de Direito Internacional Público. 12. ed. Rio de Janeiro: Forense, 2018, p. 45.
} 
ISSN 1981-3694

(DOI): $10.5902 / 1981369439249$

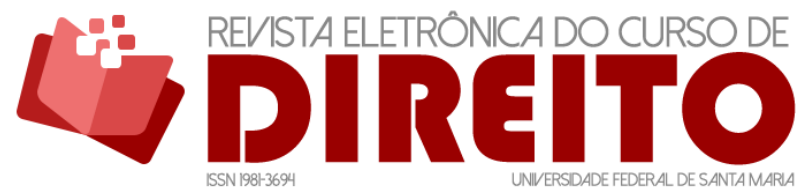

DIREITOS DE POVOS INDÍGENAS NO BRASIL: O “NÚCLEO ESSENCIAL DE DIREITOS” ENTRE DIVERSIDADE E INTEGRACIONISMO

MILENA PETTERS MELO THIAGO RAFAEL BURCKHART

caso desejarem, da vida política, econômica e social do Estado (art. 5). A Declaração protege ainda garantia de acesso a meios de comunicação (art. 16); a participação política e social (art. 18); a cooperação política (art. 19) e o reconhecimento do desenvolvimento de suas estratégias políticas (art. 23).

A Convenção 169 da OIT, apesar de não reconhecer expressamente o direito à autodeterminação, aponta para dois fatores essenciais nessa direção: o direito de consulta aos povos indígenas, reconhecido pelo artigo 6, 1, "a"; e o respeito ao direito consuetudinário dos povos indígenas, reconhecido no art. 8, 1, do mesmo instrumento.

Todos esses dispositivos normativos reforçam o segundo pilar de sustentação do núcleo essencial de direitos dos povos indígenas.

Os direitos culturais de povos indígenas estão reconhecidos na Constituição brasileira em diversos artigos. 0 caput do artigo 231 aponta para o reconhecimento da sua organização social, costumes, línguas, crenças e tradições. Além disso, a Constituição assegura o ensino bilíngue para comunidades indígenas (art. 210 , $\S 2^{\circ}$ ) e determina que o Estado deve proteger as manifestações das culturas indígenas (art. 215, $\left.\$ 1^{\circ}\right)$.

No âmbito internacional, são diversos os instrumentos normativos que garantem o direito à diversidade cultural, de todos as pessoas e comunidades, e, portanto, também dos sujeitos e coletividades indígenas. Dentre estes instrumentos, podem ser destacadas: a Convenção para a Proteção do Patrimônio Mundial, Cultural e Natural de 1972; a Declaração Universal sobre a Diversidade Cultural de 2001; a Convenção sobre a Salvaguarda do Patrimônio Cultural Imaterial de 2003; e a Convenção sobre a Proteção e Promoção da Diversidade das Expressões Culturais de 2005.

A Convenção 169 da OIT reconhece em diversos artigos direitos culturais dos povos indígenas. Nesse sentido se destaca o artigo $5^{\circ}$, "a" e "b" desta Convenção, por enfatizar que deverão ser reconhecidos e protegidos os valores e práticas sociais, culturais, religiosas e espirituais dos povos indígenas, bem como a integridade de seus valores, práticas e instituições. A Declaração Internacional sobre os Direitos de Povos Indígenas é mais contundente, protegendo o direito à identidade cultural (artigo 33) e salvaguardando o seu patrimônio cultural (artigo 31), além de sublinhar o respeito às suas tradições e costumes e a proibição de discriminação (artigo $9,11$ e 12$)$

Os três pilares de sustentação do núcleo essencial de direitos dos povos indígenas, como se observa, encontram-se inter-relacionados, de modo que há entre eles uma evidente interdependência, na medida em que a violação a um determinado direito implica, em muitos 
ISSN 1981-3694

(DOI): $10.5902 / 1981369439249$

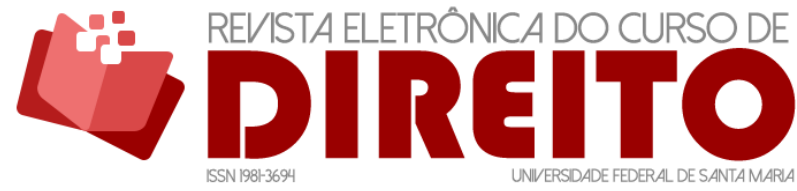

DIREITOS DE POVOS INDÍGENAS NO BRASIL: O “NÚCLEO ESSENCIAL DE DIREITOS" ENTRE DIVERSIDADE E INTEGRACIONISMO

MILENA PETTERS MELO THIAGO RAFAEL BURCKHART

casos, a violação dos demais. Pode-se afirmar, portanto, que, como os demais direitos humanos, também os direitos do núcleo essencial de direitos de povos indígenas são indivisíveis e interdependentes. Por isso é necessário compreender esses direitos no âmbito da sua intrínseca complexidade e construir políticas constitucionais intersetoriais e interseccionárias, grifo nosso, que operem no sentido de dar sentido e valor ao conjunto de direitos deste núcleo.

\section{O PARADIGMA DA DIVERSIDADE E A SUPERAÇÃO FORMAL DO INTEGRACIONSIMO HISTÓRICO}

James Tully inicia o livro "Strange multiplicity: constitutionalism in the age of diversity”, grifo nosso, partindo de um questionamento central em termos epistemológicos e políticos: "[...] can a modern Constitution recognize and accomodate cultural diversity?"26. Esta era uma questão central para o constitucionalismo desde meados dos anos 1970, período em que os movimentos culturais passaram a edificar o caleidoscópio de uma era da diversidade, que se assenta em um novo paradigma, o paradigma cultural, como afirma Alain Touraine ${ }^{27}$. De acordo com James Tully, a age of cultural diversity é marcada pelo nascimento de demandas pelo multiculturalismo, o que transforma a forma pelo qual se pensa e se concebe o constitucionalismo e os direitos humanos e fundamentais. Em efeito, abre-se espaço para o reconhecimento de novos sujeitos e novos direitos, que convergem para intensificar o sentido de legalidade e constitucionalidade em direção à liberdade coletiva e individual.

O questionamento de Tully deve ser respondido de modo afirmativo, levando-se em consideração o estado da arte do constitucionalismo contemporâneo. Em efeito, o momento político hodierno é marcado pelo renascimento das pautas identitárias e culturais, pelo retorno daquilo que Ghai Yash chama de the rise of ethnic consiousness ${ }^{28}$. Pautas que se projetaram no âmbito político e jurídico, no qual suas demandas pelo reconhecimento da diversidade ${ }^{29}$

\footnotetext{
26 Tradução nossa: "as constituições modernas podem reconhecer e acomodar a diversidade cultural?", cfe. TULLY, James. Strange multiplicity: constitutionalism in the age of diversity. New York: Cambridge University Press, 1995, p. 5.

${ }^{27}$ Para Touraine, o paradigma cultural supera aquele politico do século XVIII e o social do século XX. Cfe. TOURAINE, Alain. Un nouveau paradigme pour comprendre le monde d'aujourd'hui. Paris: Fayard, 2005.

${ }^{28}$ YASH, Ghai. Constitutionalism and the challeng of ethnic diversity. World Justice Forum, Viena, 2008.

${ }^{29}$ Para uma análise crítica do processo de reconhecimento jurídico e político da diversidade cutlural, ver: POLANCO, Héctor-Dias. Elogío a la diversidade: globalización, multiculturalismo y etnofagía. México: Siglo XXI, 2006; TULLY, James. Strange multiplicity, p. 8.
} 
ISSN 1981-3694

(DOI): $10.5902 / 1981369439249$

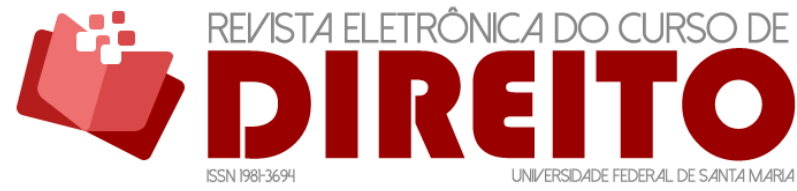

DIREITOS DE POVOS INDÍGENAS NO BRASIL: O “NÚCLEO ESSENCIAL DE DIREITOS" ENTRE DIVERSIDADE E INTEGRACIONISMO

MILENA PETTERS MELO THIAGO RAFAEL BURCKHART

passaram a integrar a dimensão do patrimônio comum do constitucionalismo democrático ${ }^{30}$. Como bem apontam Tully e Yash, esse processo encontra fundamento nos questionamentos sobre os limites do Estado-nação que reconhecia, ao longo de grande parte da modernidade, apenas um modelo de sociedade nacional. Nesse sentido, a ficção heterônoma e integracionista do Estado-nação pode ser compreendida, sob a ótica do pluralismo político, como a base de uma série de injustiças étnicas e epistemicídios.

Como observa Boaventura de Sousa Santos, o processo de construção da modernidade relegou à periferia as epistemologias do sul, as formas de conhecer e de ser no mundo que não compactuavam com o ideário de sociedade nacional moderna ${ }^{31}$. Por isso, especialmente em contextos diversificados culturalmente, como é o caso do Brasil e da América Latina, a justiça constitucional deve se pautar pela proteção da diversidade e reconhecimento das diferenças culturais do cidadãos. Como enfatiza Tully: "a just form of Constitution must begin with the full mutual recognition of the different cultures of its citizens" 32 .

Nessa perspectiva, Andrew Arato e Jean Cohen observam que o consenso moderno sobre a unificação cultural perdeu sentido com o nascimento das pautas culturais no final do século XX. Esse processo, como analisam os autores, é endossado pelas falhas do Estado-nação em lidar com o problema da pluralidade das minorias étnicas que se posicionam no interior de cada Estado. Este novo cenário comporta uma série de problemas e desafios para a soberania estatal na contemporaneidade, ao mesmo tempo em que redesenha e redimensiona a forma política e jurídica dos modelos criados ao longo da modernidade.

A globalização econômica, cultural, política e jurídica, aliada ao intercâmbio cultural intensivo e à configuração de novos arranjos políticos - novos e novíssimos movimentos sociais, novas pautas reivindicativas, novos sujeitos políticos - evidenciam a necessidade da reestruturação da forma Estado e da forma nação. Uma rearticulação voltada para a democratização cultural do Estado, através do reconhecimento da pluralidade de nações e da pluralidade étnica no interior de cada sociedade. Uma nova estrutura que venha a proteger,

\footnotetext{
${ }^{30}$ Sobre o patrimônio comum do constitucionalismo, ver: ONIDA, Valerio. La costituzione ieri e oggi. Bologna : Il Mulino, 2008. Sobre o patrimônio comum dos constitucionalismo democrático e a contribuição da América Latina para a proteção da sócio-diversidade e da biodiversidade neste contexto, consultar: MELO, Milena Petters. O Patrimônio Comum do Constitucionalismo Contemporâneo e a virada biocêntrica do "Novo" Constitucionalismo Latino-Americano. Revista Novos Estudos Jurídicos, UNIVALI, v. 18, n. 1, 2013.

${ }^{31}$ Para aprofundamentos, ver: SANTOS, Boaventura de Sousa; MENESES, Maria Paula. (Orgs.) Epistemologias do Sul. São. Paulo; Editora Cortez. 2010.

32 Tradução nossa: "uma forma justa de Constituição deve pautar-se pelo mútuo reconhecimento das diferentes culturas dos cidadãos", TULLY, James. Strange multiplicity, p. 8.
} 
ISSN 1981-3694

(DOI): 10.5902/1981369439249

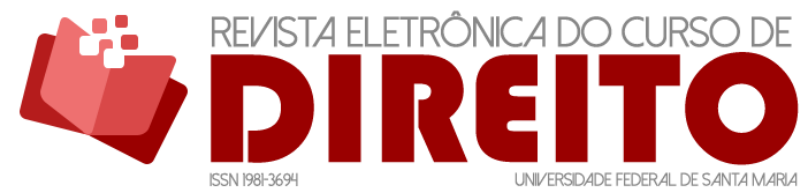

DIREITOS DE POVOS INDÍGENAS NO BRASIL: O “NÚCLEO ESSENCIAL DE DIREITOS" ENTRE DIVERSIDADE E INTEGRACIONISMO

MILENA PETTERS MELO THIAGO RAFAEL BURCKHART

valorizar e promover a diversidade por meio de políticas constitucionais direcionadas a expandir, e não a limitar, a liberdade e a igualdade no constitucionalismo democrático ${ }^{33}$.

Trata-se da necessidade de rever e repensar os fundamentos do constitucionalismo moderno. O constitucionalismo moderno nasceu no final do século XVIII, como uma nova unidade que representa uma específica forma de "legalization of political rule" ${ }^{34}$, fundada na separação dos poderes e garantia dos direitos liberais $^{35}$. As bases epistemológicas e políticas do constitucionalismo passaram a ser questionadas num primeiro momento logo após a Revolução Industrial, com a crítica de cunho social, que abriu caminho para o reconhecimento dos direitos sociais. Logo após a Segunda Guerra Mundial, com o redesenho dos direitos humanos na ordem internacional, tornou-se necessário novamente reconceber os fundamentos do constitucionalismo que se internacionalizou como ideal universal ${ }^{36}$, a partir de novos princípios de convivência, respeito e diálogo entre os povos ${ }^{37}$.

Mais recentemente, as demandas de novos sujeitos por novos direitos impulsionam uma nova fase do constitucionalismo. É nesse contexto que se formam as bases do que se chama neste trabalho de "paradigma da diversidade". Este novo paradigma foi sendo construído a partir dos processos de mobilização social pelo direito à diferença e pela igualdade na diversidade, que foram postos em cena em meados dos anos 1970 em diante, produzindo mudanças tanto do ponto de vista social, moral e ético, quanto do ponto de vista político e jurídico. Processos que repercutiram, e repercutem, e em diversos aspectos da vida.

No que se refere em específico aos povos indígenas, a construção deste paradigma permitiu a projeção de suas pautas reivindicatórias em âmbitos multifacetados, com maior ou menor tensão. Como assinalam diversos autores, talvez Stuart Hall ${ }^{38}$ de modo mais enfático, o processo de reconhecimento de novas identidades não ocorreu de modo consensual e harmônico nas diferentes facetas da sociedade. Em efeito, diversos grupos se insurgiram desde então

33 Cfe. ARATO, Andrew; COHEN, Jean; BUSEKIST, Astrid von. Forms of pluralism and democratic constitutionalism. New York: Columbia University Press, 2018.

34 Tradução nossa: “uma legalização da politica institucional”, GRIMM, Dieter. Constitutionalism: past, presente, future. Oxford: Orford University Press, 2016, p. 4.

${ }^{35} \mathrm{Cfe}$. CANOTILHO, José Joaquim Gomes. Direito Constitucional e Teoria da Constituição. Op. Cit.

${ }^{36} \mathrm{Cfe}$. ACKERMAN, Bruce. The rise of the world constitutionalism. Virginia Law Review 83, n. 4, 1997.

${ }^{37}$ Como aponta o jurista francês Dominique Rousseau, uma dimensão esquecida da teoria constitucional e do constitucionalismo ganhou relevância desde então, qual seja, sua dimensão utópica. Para Rousseau, a utopia é uma força constitutiva do constitucionalismo moderno - assim como as já referidas separação dos poderes e garantia de direitos -, sendo o elemento catalisador que permite dimensionar o reconhecimento de novos direitos a partir da efetivação daqueles já conquistados. ROUSSEAU, Dominique. Le droit constitutionnel continue: institutions, garantie des droits et utopie. Revue de droit publique et de la science politique en France e à l'étranger, v 130, 6, 2014.

${ }^{38} \mathrm{Cfe}$. HALL, Stuart. A identidade cultural na pós-modernidade. Rio de Janeiro: D\&P , 2010. 
ISSN 1981-3694

(DOI): 10.5902/1981369439249

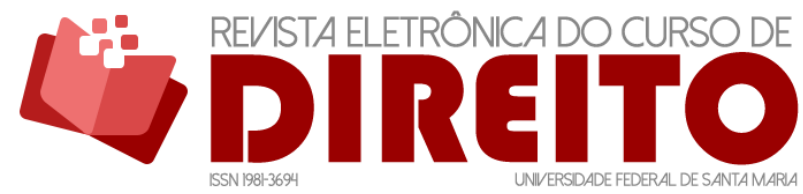

DIREITOS DE POVOS INDÍGENAS NO BRASIL: O “NÚCLEO ESSENCIAL DE DIREITOS" ENTRE DIVERSIDADE E INTEGRACIONISMO

MILENA PETTERS MELO THIAGO RAFAEL BURCKHART

reivindicando uma perspectiva estática, pura e hierarquizada de identidade cultural $^{39}$, subvertendo a lógica interna do paradigma da diversidade que tem por pressuposto o respeito da pluralidade e a promoção do diálogo intercultural.

Em compasso com a afirmação do paradigma da diversidade, o empoderamento político e comunicativo dos povos indígenas gerou repercussões políticas e jurídicas inusitadas, especialmente a projeção normativa de seus direitos. A Constituição de 1988, que pode ser interpretada também como um dos frutos desse processo mais amplo, impulsionou normativamente a superação do integracionismo histórico que marcou a política indigenista no Brasil e em grande parte da América Latina.

O integracionismo nas políticas indígenas pode ser compreendido como uma ação governamental que busca integrar os índios na comunhão nacional, isto é, no modelo de vida que a população do Estado majoritariamente partilha que, no Brasil, reflete uma dinâmica de sociedade não-indígena, o que, portanto, nega a própria autonomia cultural e política desses grupos.

Como observa Raquel Fajardo, as políticas integracionistas diferenciam-se das políticas assimilacionistas. De acordo com a autora, as políticas assimilacionistas, impetradas em grande parte do continente latino-americano durante as primeiras décadas descolonização, envolvem a integração dos povos autóctones na comunhão nacional sem que eles possam expressar suas culturas. Por outro lado, o integracionismo permite que esses povos reproduzam suas culturas e identidades, sem que interfiram diretamente na dinâmica de relações dominantes da cultura nacional ${ }^{40}$.

No Brasil, o integracionismo marcou a política indigenista desde a construção do Serviço de Proteção ao Índio, em 1910. Influenciado pelo positivismo e pela visão evolucionista social imperante naquela época, a política integracionista visava paulatinamente assimilar os "silvícolas" 41 à sociedade nacional. A vontade de integrar condizia com interesses mais amplos, de cunho político e econômico, que, em síntese, buscava com que os povos indígenas, a partir de sua integração na sociedade brasileira, perderiam o interesse em permanecer em suas terras,

\footnotetext{
39 No Brasil, o caso mais emblemático talvez seja a recente ascensão dos "evangélicos" na política institucional brasileira. Trata-se de um grupo que, aliado aos ruralistas no Congresso Nacional e demais instâncias de poder, operam no sentido de questionar a legitimidade dos direitos de povos indígenas.

40 FAJARDO, Raquel. Aos 20 anos da Convenção 169 da OIT: balanço e desafios da implementação dos direitos dos povos indígenas na América Latina. In: VERDUM, Ricardo (Orgs.). Povos indígenas: constituições e reformas políticas na América Latina. Brasília: Instituto de Estudos Socioeconômicos, 2009. ${ }^{41}$ Silvícolas é um termo atualmente considerado pejorativo para referir-se aos povos indígenas.
} 
ISSN 1981-3694

(DOI): 10.5902/1981369439249

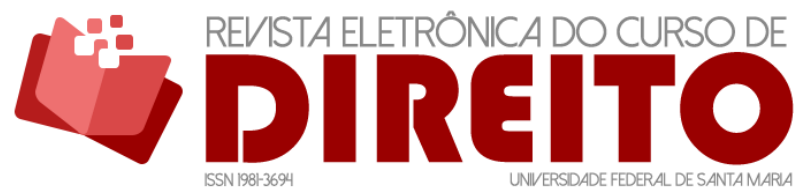

DIREITOS DE POVOS INDÍGENAS NO BRASIL: O “NÚCLEO ESSENCIAL DE DIREITOS" ENTRE DIVERSIDADE E INTEGRACIONISMO

MILENA PETTERS MELO THIAGO RAFAEL BURCKHART

o que abriria espaço para a atuação de grupos econômicos em sua aquisição e exploração ${ }^{42}$. 0 Estatuto do Índio (Lei n. 6.001 de 1973), logo no seu primeiro artigo deixa evidente sua intenção integracionista ao predispor que "esta lei regula a situação jurídica dos índios ou silvícolas e das comunidades indígenas, com o propósito de preservar a sua cultura e integrá-los, progressiva e harmoniosamente, à comunhão nacional"43, grifo nosso.

O integracionismo, ao apelar para uma determinada dinâmica política do multiculturalismo, no qual as diferentes culturas convivem sob o signo frágil da tolerância, impossibilita, na maior parte do tempo, o diálogo intercultural entre as culturas e o aprendizado mútuo de culturas híbridas ${ }^{44}$. Ao mesmo tempo, a tendência à assimilação, em função da heteronomia da cultura dominante, impele à desagregação das culturas originais ${ }^{45}$.

A Constituição de 1988, embora seja categorizada por Raquel Fajardo como tendo sido o fruto de um ciclo multicultural de novas Constituições na América Latina, abre espaço para a interculturalidade, apesar de não a prever expressamente em seu texto, como o fazem as mais recentes constituições do Equador (2008) e da Bolívia (2009).

Com a projeção normativa, no plano constitucional e internacional, das demandas políticas para a preservação do patrimônio cultural e a proteção da diversidade cultural e pela escolha constitucional adotada no Brasil em 1988, torna-se manifesta, portanto, ao menos do ponto de vista teórico e jurídico-formal, a superação do integracionismo histórico das políticas indígenas. Referida superação encontra fulcro na Constituição Federal de 1988 e nos desdobramentos jurídicos que dela emergiram. Observa-se, nesse sentido, a possibilidade de convivência harmônica de diferentes povos e diferentes nações no espaço territorial brasileiro, impulsionando o diálogo intercultural e a solidariedade social como mecanismos estratégicos para evitar o conflito e estimular a aprendizagem recíproca, consolidando o convívio pacífico, democrático e produtivo entre diferentes epistemologias e modos de viver.

\footnotetext{
${ }^{42}$ CUNHA, Manuela Carneiro da. Índios do Brasil: história, direitos e cidadania. São Paulo: Claro Enigma, 2012.

${ }^{43}$ Neste artigo defende-se a ideia de que referido artigo estaria revogado com o advento da Constituição de 1988, pois esta última reconhece a pluralidade no âmbito de uma nova forma de gestão política do pluralismo.

${ }^{44}$ Para analisar as críticas ao multiculturalismo, ver: DULCE, Maria José Fariñas. Democracia y pluralismo: una mirada hacia la emancipación. Madrid : Dykinson, 2014; ZIZEK, Slavoj. In defense of lost causes. New York: Verso, 2008.

${ }^{45}$ MELO, Milena Petters. Entre Igualdade e Diversidade: Globalização, Migrações, Direitos Humanos e Relações Interculturais. In: PRONER, Caroline; BARBOZA, Estefania Maria de Queiroz; GODOY, Gabriel Gualiano de (org.) Migrações, Políticas e Direitos Humanos sob as perspectivas do Brasil, Itália e Espanha. Curitiba: Juruá, 2015.
} 


\section{A TESE DO MARCO TEMPORAL E A PERMANÊNCIA DO INTEGRACIONISMO}

Não obstante a superação formal do integracionismo histórico promovida pelo texto constitucional de 1988, é certo que inúmeras práticas integracionistas ainda marcam as políticas indigenistas. Nesse cenário marcado pela violação de direitos e pelos riscos de retrocesso, ganha destaque a tese do marco temporal.

A tese do marco temporal foi desenvolvida no Supremo Tribunal Federal, em 2009, no julgamento do leading case Raposa/Serra do Sol. O caso foi originado por uma Ação Popular impetrada em 2005 pelo Senador à época Augusto Afonso Botelho Neto (PT/RR) em face da União. Logo após a terra indígena ter sido homologada e formalmente registrada, a Ação contestava e requeria a impugnação do modelo de demarcação contínua da Terra Indígena Raposa Serra do Sol, requerendo ainda a suspensão liminar dos efeitos da Portaria 534/2005 e do decreto homologatório assinado pelo então Presidente da República Luiz Inácio Lula da Silva, com o objetivo de declarar sua nulidade e inconstitucionalidade. Esta Ação popular alastrou as discussões políticas e jurídicas relativas à demarcação da terra indígena no âmbito judiciário.

0 processo de julgamento do caso pelo Supremo Tribunal Federal iniciou em 27 de agosto de 2008. O relator do caso, ministro Carlos Ayres Britto proferiu seu voto, tendo julgado improcedente a Ação Popular, fazendo assentar a condição de indígena à terra Raposa/Serra do Sol em tua totalidade e de forma contínua. Em seu voto, o ministro inovou ao estabelecer os marcos regulatórios relativos ao processo de demarcação das terras indígenas, quais sejam, 1) marco temporal de ocupação ${ }^{46}$; 2) marco da tradicionalidade da ocupação; 3) marco da concreta abrangência fundiária e da finalidade prática da ocupação tradicional; e 4) marco do conceito fundiariamente extensivo do chamado princípio da proporcionalidade ${ }^{47}$.

Logo após o relator, o ministro Carlos Alberto Menezes Direito pediu vistas do processo. 0 julgamento foi retomado em dezembro de 2008, com o oferecimento do voto parcialmente divergente do ministro Menezes Direito. Segundo Erica Magami Yamada e Luis Fernando Villares, ciente de que um voto contrário à demarcação contínua da Terra Indígena não seria bem recebido pela maioria do Plenário, o que o colocaria numa posição desconfortável, esse ministro estabeleceu 19 condicionantes, ou ressalvas, às demarcações. Essas 19 ressalvas somam-se aos

\footnotetext{
${ }^{46}$ A tese do marco temporal de ocupação afirma que os povos indígenas só possuem direito às terras que nelas se encontravam na data da promulgação da Constituição de 1988, sendo uma restrição judicialmente criada no caso Raposa Serra do Sol.

47 SUPREMO TRIBUNAL FEDERAL. Petição 3.388/RR, julgamento 19/03/2009, Relator: Min. Carlos Britto, Órgão Julgador: Tribunal Pleno, p. 295-308.
} 
ISSN 1981-3694

(DOI): $10.5902 / 1981369439249$

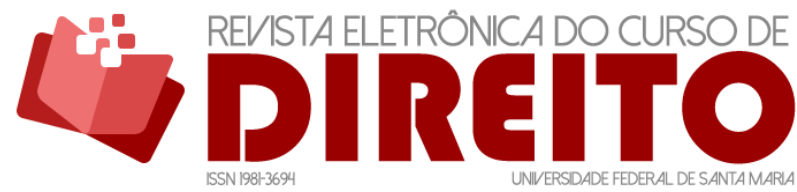

DIREITOS DE POVOS INDÍGENAS NO BRASIL: O “NÚCLEO ESSENCIAL DE DIREITOS" ENTRE DIVERSIDADE E INTEGRACIONISMO

MILENA PETTERS MELO THIAGO RAFAEL BURCKHART

quatro marcos estabelecidos no voto do relator como um conjunto de medidas a serem observadas no decorrer do processo demarcatório para a caracterização de uma terra como indígena. Dentre esses marcos regulatórios, o mais polêmico e que gerou maior repercussão foi o marco temporal. De acordo com esse critério, os povos indígenas não possuiriam direito às suas terras caso não estivessem nelas na data da promulgação da Constituição de 1988. Este parâmetro não encontra fulcro em qualquer dispositivo constitucional ou mesmo em instrumentos internacionais de proteção dos direitos humanos, sendo, portanto, um critério extrajurídico criado no caso específico para dar uma interpretação restritiva aos direitos de povos indígenas ${ }^{48}$.

Posteriormente ao voto do ministro Carlos Alberto Menezes Direito, passaram a votar favoravelmente à constitucionalidade da demarcação da terra indígena os ministros Carmen Lúcia Antunes Rocha, Enrique Ricardo Lewandowski, Eros Roberto Grau, Joaquim Benedito Barbosa Gomes e Antonio Cezar Peluso, havendo um novo pedido de vistas pelo ministro Marco Aurélio Mendes de Faria Mello. O julgamento da Ação retornou no dia 18 de abril de 2009, na qual o ministro Marco Aurélio Mendes de Faria Mello proferiu seu voto divergente, pela inconstitucionalidade da demarcação da terra. Nesta mesma data o ministro Celso de Mello proferiu seu voto favorável à demarcação, e em razão do interrompimento da sessão, o ministro Gilmar Mendes, então Presidente do Supremo Tribunal Federal, proferiu seu voto acompanhando o relator com o acréscimo das ressalvas realizadas pelos ministros Carlos Britto e Menezes Direito.

A Ação foi, portanto, julgada parcialmente procedente, tendo sido vencidos os ministros Joaquim Benedito Barbosa Gomes e Marco Aurélio Mendes de Faria Mello, o primeiro por julgá-la totalmente improcedente inclusive no que se referem às ressalvas e marco temporal, e o segundo por julgá-la totalmente procedente. Foi “declarada, então, a constitucionalidade da demarcação contínua da Terra Indígena Raposa Serra do Sol e afirmada a constitucionalidade do procedimento administrativo-demarcatório" ${ }^{49}$. A constitucionalidade foi condicionada às salvaguardas institucionais majoritariamente aprovadas pelo Plenário. Referidas salvaguardas ${ }^{50} \mathrm{e}$

\footnotetext{
${ }^{48}$ CUNHA, Manuela Carneiro da; BARBOSA, Samuel (Orgs.). Direitos indígenas em disputa. São Paulo: Editora da Unesp, 2018.

49 SUPREMO TRIBUNAL FEDERAL. Petição 3.388/RR, p. 241.

50 Salvaguardas: “(I) o usufruto das riquezas do solo, dos rios e dos lagos existentes nas terras indígenas (art. 231, § $2^{\circ}$, da Constituição Federal) pode ser relativizado sempre que houver, como dispõe o art. 231, $\S 6^{\circ}$, da Constituição, relevante interesse público da União, na forma de lei complementar; (II) o usufruto dos índios não abrange o aproveitamento de recursos hídricos e potenciais energéticos, que dependerá sempre de autorização do Congresso Nacional; (III) o usufruto dos índios não abrange a pesquisa e lavra das riquezas minerais, que dependerá sempre de autorização do Congresso Nacional, assegurando-se-lhes
} 
DIREITOS DE POVOS INDÍGENAS NO BRASIL: 0 “NÚCLEO ESSENCIAL DE DIREITOS” ENTRE DIVERSIDADE E INTEGRACIONISMO

MILENA PETTERS MELO THIAGO RAFAEL BURCKHART

marcos regulatórios foram justificados no acórdão pela "superlativa importância histórico-

cultural da causa", grifo nosso.

Nesse sentido, embora a Suprema Corte tenha solucionado o caso Raposa Serra do Sol, reconhecendo a constitucionalidade da demarcação da terra indígena mediante o estabelecimento das referidas salvaguardas e do marco temporal, fato é que as repercussões jurídicas e políticas desta atuação do Supremo Tribunal Federal não se restringiram a este caso. A decisão gerou reflexos políticos e jurídicos no que se refere à constitucionalidade das referidas salvaguardas e da tese do marco temporal. Diversos especialistas, juristas, antropólogos e

a participação nos resultados da lavra, na forma da lei; (IV) o usufruto dos índios não abrange a garimpagem nem a faiscação, devendo, se for o caso, ser obtida a permissão de lavra garimpeira; (V) o usufruto dos índios não se sobrepõe ao interesse da política de defesa nacional; a instalação de bases, unidades e postos militares e demais intervenções militares, a expansão estratégica da malha viária, a exploração de alternativas energéticas de cunho estratégico e o resguardo das riquezas de cunho estratégico, a critério dos órgãos competentes (Ministério da Defesa e Conselho de Defesa Nacional), serão implementados independentemente de consulta às comunidades indígenas envolvidas ou à FUNAI; (VI) a atuação das Forças Armadas e da Polícia Federal na área indígena, no âmbito de suas atribuições, fica assegurada e se dará independentemente de consulta às comunidades indígenas envolvidas ou à FUNAI; (VII) o usufruto dos índios não impede a instalação, pela União Federal, de equipamentos públicos, redes de comunicação, estradas e vias de transporte, além das construções necessárias à prestação de serviços públicos pela União, especialmente os de saúde e educação; (VIII) o usufruto dos índios na área afetada por unidades de conservação fica sob a responsabilidade do Instituto Chico Mendes de Conservação da Biodiversidade; (IX) o Instituto Chico Mendes de Conservação da Biodiversidade responderá pela administração da área da unidade de conservação também afetada pela terra indígena com a participação das comunidades indígenas, que deverão ser ouvidas, levando-se em conta os usos, tradições e costumes dos indígenas, podendo para tanto contar com a consultoria da FUNAI; $(X)$ o trânsito de visitantes e pesquisadores não índios deve ser admitido na área afetada à unidade de conservação nos horários e condições estipulados pelo Instituto Chico Mendes de Conservação da Biodiversidade; (XI) devem ser admitidos o ingresso, o trânsito e a permanência de não-índios no restante da área da terra indígena, observadas as condições estabelecidas pela FUNAI; (XII) o ingresso, o trânsito e a permanência de não índios não pode ser objeto de cobrança de quaisquer tarifas ou quantias de qualquer natureza por parte das comunidades indígenas; (XIII) a cobrança de tarifas ou quantias de qualquer natureza também não poderá incidir ou ser exigida em troca da utilização das estradas, equipamentos públicos, linhas de transmissão de energia ou de quaisquer outros equipamentos e instalações colocadas a serviço do público, tenham sido excluídos expressamente da homologação, ou não; (XIV) as terras indígenas não poderão ser objeto de arrendamento ou de qualquer ato ou negócio jurídico que restrinja o pleno exercício do usufruto e da posse direta pela comunidade indígena ou pelos índios (art. 231, § $2^{\circ}$, Constituição Federal, c/c art. 18, caput, Lei $\left.n^{\circ} 6.001 / 1973\right)$; (XV) é vedada, nas terras indígenas, a qualquer pessoa estranha aos grupos tribais ou comunidades indígenas, a prática de caça, pesca ou coleta de frutos, assim como de atividade agropecuária ou extrativa (art. 231, § $2^{\circ}$, Constituição Federal, c/c art. 18, § $1^{\circ}$, Lei $\mathrm{n}^{\circ}$ 6.001/1973); (XVI) as terras sob ocupação e posse dos grupos e das comunidades indígenas, o usufruto exclusivo das riquezas naturais e das utilidades existentes nas terras ocupadas, observado o disposto nos arts. 49, XVI, e 231, § $3^{\circ}$, da CR/88, bem como a renda indígena (art. 43 da Lei $\mathrm{n}^{\circ}$ 6.001/1973), gozam de plena imunidade tributária, não cabendo a cobrança de quaisquer impostos, taxas ou contribuições sobre uns ou outros; (XVII) é vedada a ampliação da terra indígena já demarcada; (XVIII) os direitos dos índios relacionados às suas terras são imprescritíveis e estas são inalienáveis e indisponíveis (art. 231 , § $4^{\circ}$, CR/88); e (XIX) é assegurada a participação dos entes federados no procedimento administrativo de demarcação das terras indígenas, encravadas em seus territórios, observada a fase em que se encontrar o procedimento. SUPREMO TRIBUNAL FEDERAL. Petição 3.388/RR, p. 416-418. 
ISSN 1981-3694

(DOI): 10.5902/1981369439249

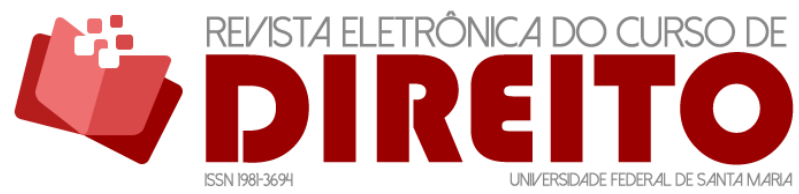

DIREITOS DE POVOS INDÍGENAS NO BRASIL: O “NÚCLEO ESSENCIAL DE DIREITOS" ENTRE DIVERSIDADE E INTEGRACIONISMO

MILENA PETTERS MELO THIAGO RAFAEL BURCKHART

representantes de instituições indigenistas criticaram a posição do Supremo Tribunal, denunciando inconstitucionalidades em determinados pontos das salvaguardas. 0 debate, que mantém aberta a questão, gera insegurança jurídica e muitos problemas para grande parte dos povos indígenas que ainda reivindicam o procedimento de demarcação de suas terras, ou mesmo daqueles que estão em análise.

De acordo com Luis Fernando Villares e Erica Magami Yamada as discutíveis salvaguardas podem ser descritas da seguinte forma: "algumas são interpretações ou repetições do texto constitucional e legal (as de número 1, 2, 3, 4, 14, 15, 16, 18), outras, comandos contrários aos já estabelecidos na convenção 169 da Organização Internacional do Trabalho (OIT), (5, 6, 7)", além disso, há "a criação de enunciados normativos pelas ressalvas 11, 12, 13, 17, e 19"51. Apesar de ter sido definido em resposta aos embargos de declaração impetrados pelo Ministério Público Federal, fazendo com que os efeitos das salvaguardas se restringissem ao caso Raposa Serra do Sol, a Segunda Turma do Supremo Tribunal Federal, presidida pelo ministro Gilmar Mendes, aplicou as salvaguardas e a tese do marco temporal em outras decisões ${ }^{52}$, contrastando com a jurisprudência da Primeira Turma e do próprio Plenário do Supremo Tribunal Federal.

Além disso, a decisão também abriu o caminho para a aplicação das salvaguardas e da tese do marco temporal, mesmo aquelas que geraram divergências, por juízes federais e estaduais em causas envolvendo a demarcação de terras indígenas em todo o território nacional. Três pareceres da Advocacia-Geral da União também foram expedidos com o intuito de obrigar a Administração Pública Federal a dar efetivo cumprimento, em todos os processos de demarcação de terras indígenas às condições fixadas na decisão do Supremo Tribunal Federal (STF) na Petição n. 3.388 de Roraima (PET n. 3388/RR).

O Parecer Advocacia-Geral da União, datado de 19 de julho de 2017 e ainda vigente mas com seus efeitos suspensos em razão da concessão de liminar pelo STF para a suspensão de sua

\footnotetext{
51 YAMADA, Eica Magami; VILLARES, Luiz Fernando. Julgamento da Terra Indígena Raposa Serra do Sol: todo dia era dia de índio. Revista Direito GV, 2010, vol.6, n.1, p. 147. Para uma crítica às salvaguardas, ver: MIRAS, Julia Trujillo (Org.). Makunaíma Grita!: Terra indígena Raposa Serra do Sol e os direitos constitucionais no Brasil. Rio de Janeiro : Beco do Azougue, 2009; e KAYSER, Hartmut-Emanuel. Os direitos dos povos indígenas do Brasil: desenvolvimento histórico e estágio atual. Porto Alegre: Sérgio Antonio Fabris, 2010.

52 "Ela [a tese do marco temporal] fundamentou a anulação das portarias de reconhecimento das Terras Indígenas Limão Verde, do poro Terena Guyaroké, do povo Guarani-Kaiowá, ambos em Mato Grosso do Sul, e Porquinhos do Povo Canela Apanyekrá, no Maranhão, pela Segunda Turma do Supremo Tribunal Federal em 2014 e 2015", cf. FERNANDES, Pádua. A proteção das terras indígenas no direito internacional: marco temporal, provincialnismo constitucional e produção legal da ilegalidade. In: BARBOSA, Samuel; CUNHA, Manuela Cardeiro (Orgs.). Direitos dos Povos Indígenas em disputa. São Paulo : Editora Unesp, 2018, p. 140.
} 
ISSN 1981-3694

(DOI): 10.5902/1981369439249

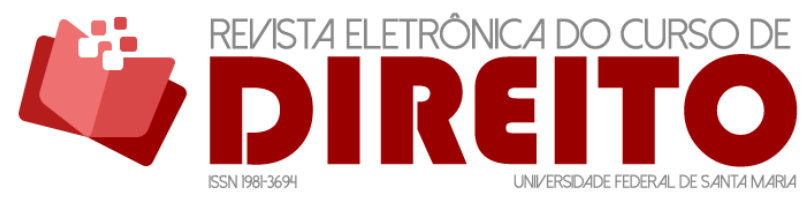

DIREITOS DE POVOS INDÍGENAS NO BRASIL: O “NÚCLEO ESSENCIAL DE DIREITOS" ENTRE DIVERSIDADE E INTEGRACIONISMO

MILENA PETTERS MELO THIAGO RAFAEL BURCKHART

eficácia nacional ${ }^{53}$, justifica a medida com o argumento de que as salvaguardas "tem sido reafirmadas em diversos outros julgamentos do próprio Supremo Tribunal Federal, tornando indubitável a consolidação e estabilização normativa das salvaguardas institucionais" ${ }^{54}$. 0 referido parecer, ao obrigar os órgãos da Administração Pública Federal a fazer cumprir o marco temporal e as salvaguardas institucionais, mostra-se como uma medida ainda mais dramaticamente prejudicial aos povos indígenas. Isso porque a Administração Pública Federal é responsável pelo processo demarcatório das terras indígenas.

Já no âmbito do Poder Legislativo, se propõe a tentativa de legalizar do marco temporal, que consta de vários Projetos de Lei (PL 490/2007; PL 1.216/2015; PL 1.218/2015; PL 7.813/2017). O Projeto de Lei (PL) 490/2007, por exemplo, sequer aceita a exceção do esbulho ${ }^{55}$. As propostas são polêmicas tendo em vista que o Congresso Nacional possui uma série de bancadas, sendo as mais destacadas a "bancada do boi", que congrega os latifundiários do país e donos do agronegócio, "da bala", que congrega os apoiadores de militares e do armamento, e "da bíblia", que representa os "evangélicos" neopentecostais e católicos radicais - que são abertamente contrários aos povos indígenas e à demarcação de suas terras, grifo nosso.

Assim, as consequências da decisão do STF no caso Raposa Serra do Sol somam-se às já conflituosas relações do Estado com os povos indígenas que marcam a história brasileira. Do ponto de vista da teoria constitucional, este caso demonstra um conflito hermenêutico sobre o significado da Constituição e a compreensão sistemática do texto constitucional, especialmente no que toca a interpretação da extensão dos dispositivos que protegem os direitos dos povos indígenas. Uma compreensão que, na omissão da sociedade aberta dos intérpretes da Constituição, passa a se estabelecer no Supremo Tribunal Federal, por excelência, em sede do controle de constitucionalidade.

\footnotetext{
${ }^{53} \mathrm{Na}$ data de 7 de maio de 2020, no âmbito do Recurso Extraordinário n. 1.017.365, o Supremo Tribunal Federal deferiu liminar concedendo a tutela provisória incidental requerida e ampliou a suspensão dos efeitos do Parecer n. ${ }^{\circ} 001 / 2017$ da Advocacia Geral da União (AGU) para todos os casos nacionais. Cfe. SUPREMO TRIBUNAL FEDERAL. Recurso Extraordinário n. 1.017.365, Relator: Edson Fachin, 2020. Da mesma forma, cabe mencionar a Nota Técnica n. $1 / 2020 / 6^{a}$ da Sexta Câmara de Coordenação e Revisão do Ministério Publico Federal sobre o Marco Temporal, no qual aponta sua inconstitucionalidade: MINISTERIO PUBLICO FEDERAL. Nota Técnica n. $1 / 2020 / 6^{a}$ CCR/MPF, Procuradoria Geral da Republica, 2020. Disponível em: http://www.mpf.mp.br/pgr/documentos/document11.pdf. Acesso em: 23 ago. 2020.

${ }^{54}$ ADVOCACIA-GERAL DA UNIÃO. Parecer n. 001/2017/GAB/CGU/AGU, Interessado: Casa Civil da Presidência da República. Diário Oficial da União, 19 jul 2017.

${ }^{55}$ CUNHA, Manuela Carneiro da. Índios na Constituição. Novos Estudos. CEBRAP, v. 37, p. 429-443, 2018.
} 
ISSN 1981-3694

(DOI): $10.5902 / 1981369439249$

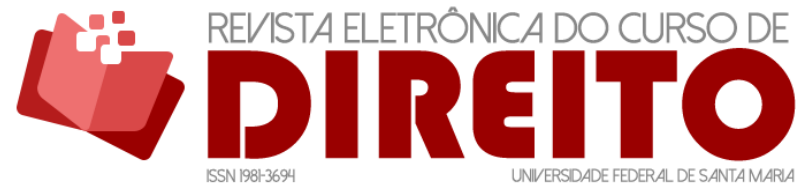

DIREITOS DE POVOS INDÍGENAS NO BRASIL: O “NÚCLEO ESSENCIAL DE DIREITOS" ENTRE DIVERSIDADE E INTEGRACIONISMO

MILENA PETTERS MELO THIAGO RAFAEL BURCKHART

É evidente que a aplicação da tese do marco temporal obsta os direitos de povos indígenas às suas terras, em função de uma interpretação infundada e restritiva. Infundada, pelo fato objetivo de não se encontrar qualquer fundamento jurídico para a referida tese. Restritiva, em virtude da tese não levar em consideração os processos de esbulho ocorridos e intensificados durante a ditadura militar com a marcha para o Oeste e tantas outras violências que poderiam ser debatidas.

Nesse sentido, a aplicação da tese do marco temporal e das salvaguardas que são contraditórias e geram insegurança jurídica e tensão política, representa uma violação não somente ao direito à terra, mas ao conjunto do núcleo essencial de direitos, conforme acima explicitado. Isto porque os pilares que formam o núcleo essencial de direitos de povos indígenas não podem ser compreendidos como apartados ou estanques, pois o gozo de um direito implica necessariamente a sua inter-relação com outro. Da mesma forma, a restrição ou violação a um direito implica na restrição ou violação dos demais.

Nesse contexto, a tese do marco temporal pode ser entendida como a continuidade, por meios alternativos, do integracionismo histórico. Um abstruso desdobramento da decisão política que, ao negar aos povos indígenas o seu direito à terra, oferece-lhes a sua integração à comunhão nacional como forma alternativa de sobrevivência, em detrimento de suas terras, suas práticas culturais e de sua autodeterminação.

No momento em que o Estado, seja por meio do Judiciário, do Executivo ou do Legislativo, nega o direito à terra dos povos indígenas, um direito originário e constitucionalmente assegurado, por meio de uma estratégia hermenêutica infundada e restritiva, compromete-se na perpetuação das relações de dominação, exclusão e opressão destes povos. Neste desvio, o Estado dá sustentação para a violação contínua e massiva direitos territoriais, culturais, políticos e ambientais dos povos indígenas ${ }^{56}$. Nessa doreção de sentido, a tese do marco temporal pode ser analisada e descrita como a permanência de uma relação de violência simbólica, como bem define Pierre Bourdieu ${ }^{57}$, inscrita em uma pragmática da violência.

\footnotetext{
56 Para aprofundamentos sobre uma visão crítica em relação ao marco temporal, consultar a seguinte coletânea: CUNHA, Manuela Carneiro da; BARBOSA, Samuel (Orgs.). Direitos indígenas em disputa. Op. Cit.

${ }^{57} \mathrm{O}$ conceito de "violência simbólica" foi criado pelo sociólogo francês Pierre Bourdieu para designar uma relação social em que o "dominador" exerce um tipo de violência indireta, não física, simbólica sobre os "dominados", muitas vezes quase invisível ou mesmo em contradição com as promessas da modernidade. No caso da tese do marco temporal, pode-se afirmar que esta cumpre uma função de dominação simbólica na medida em que subverte a promessa do texto constitucional, realocando a questão indígena em uma perspetiva de relação integracionista. Cfe. BOURDIEU, Pierre. O poder simbólico. Lisboa: Difel, 1989.
} 
ISSN 1981-3694

(DOI): $10.5902 / 1981369439249$

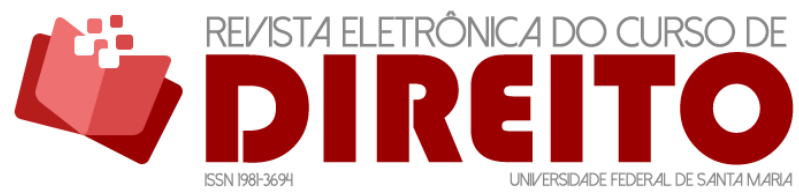

DIREITOS DE POVOS INDÍGENAS NO BRASIL: O “NÚCLEO ESSENCIAL DE DIREITOS” ENTRE DIVERSIDADE E INTEGRACIONISMO

MILENA PETTTERS MELO THIAGO RAFAEL BURCKHART

Entende-se, portanto, que não há motivos para uma interpretação restritiva dos direitos de povos indígenas senão em função de uma vontade política travestida de elementos supostamente jurídicos. Demostra-se claro que o paradigma da diversidade e sua relação com a causa indígena, encontra no Brasil uma série de obstáculos na prática política, cultural e judicial, o que relega os direitos constitucionais de povos indígenas a uma constante ameaça de inefetividade. Contudo, é especialmente nos momentos de falta de lucidez política que a Constituição se apresenta necessária e é por isso que cresce em relevância a defesa do núcleo essencial de direitos de povos indígenas, na salvaguarda da força normativa da Constituição.

\section{CONCLUSÃO}

O núcleo essencial de direitos dos povos indígenas, que deflui da análise da Constituição de 1988 em diálogo com o plano internacional de proteção dos direitos humanos, representa uma substancial conquista para os povos das multifacetadas nações indígenas.

O núcleo essencial de direitos pode ser definido como um conjunto de direitos estruturados em três pilares interdependentes que comportam, respectivamente, os direitos territoriais e ambientais, o direito à autodeterminação dos povos indígenas e os direitos culturais de povos indígenas.

Sob a ótica teórico-constitucional este núcleo essencial garante a convivência dos sujeitos e povos indígenas com a organização sociocultural que marca a sua identidade e os demais aspectos que se relacionam diretamente com sua existência: terra, meio ambiente, autoorganização política, jurídica e social. Esta conquista normativa representa em termos simbólicos a possibilidade de libertação dos povos indígenas das práticas estatais integracionistas que, historicamente, atuaram no sentido de negar ou desrespeitar as suas especificidades culturais. Ao mesmo tempo, essas aquisições evolutivas na proteção das especificidades desses sujeitos comporta, finalmente, a devida proteção jurídica e valorização da cultura indígena como constitutiva da identidade cultural do povo brasileiro e, portanto, se relaciona com a proteção da nossa abonada diversidade.

Em compasso com a afirmação do paradigma da diversidade, o empoderamento político e comunicativo dos povos indígenas gerou repercussões políticas e jurídicas inusitadas e relevantes. A Constituição de 1988, que pode ser interpretada também como um dos frutos desse processo mais amplo, impulsionou normativamente a superação do integracionismo histórico que marcou a política indigenista no Brasil e em grande parte da América Latina. 
ISSN 1981-3694

(DOI): $10.5902 / 1981369439249$

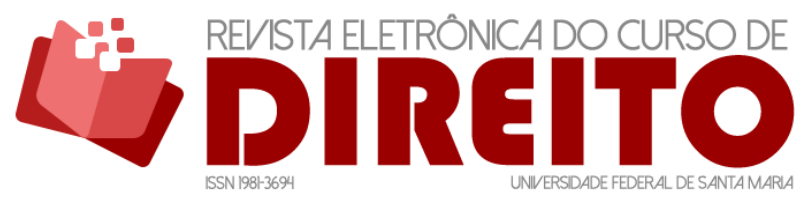

DIREITOS DE POVOS INDÍGENAS NO BRASIL: O “NÚCLEO ESSENCIAL DE DIREITOS” ENTRE DIVERSIDADE E INTEGRACIONISMO

MILENA PETTERS MELO THIAGO RAFAEL BURCKHART

A tese do marco temporal, entretanto, se coloca como um concreto impedimento ao reconhecimento material da diversidade cultural, na medida em que esta tese é uma interpretação restritiva aos direitos territoriais de povos indígenas. Além disso, a tese viola não somente os direitos à terra, mas o "núcleo essencial de direitos", tendo em vista a interconexão neste conjunto de direitos. Assim, a afirmação da tese do marco temporal contribui para a permanência, ou retorno, de práticas integracionistas na estrutura estatal brasileira, o que impacta diretamente a estrutura e eficácia do núcleo essencial de direitos de povos indígenas no país, grifo nosso.

A tese do marco temporal comprova que permanecem abertos os conflitos agrários no Brasil, bem como uma visão deturpada sobre a própria cultura indígena e sobre o papel da terra na cosmovisão dos povos autóctones. Da mesma forma, a tese demonstra que os mecanismos de violência impetradas pelo Estado a esses povos permanecem vigentes, tendo se adequado também a um determinado modelo de discurso judicial. Embora o Supremo Tribunal Federal já tenha sinalizado um ponto de inflexão na interpretação da tese do marco temporal, no sentido de se posicionar de forma contrária a ela na Ação Direta de Inconstitucionalidade n. 3239/2017, na Ação de Constitucionalidade por Omissão n. 304/2017 e mais recentemente no Recurso Extraordinário n. 1.017.365/2020, permanece ainda a incerteza de sua aplicação por parte de juízes de instâncias inferiores, da mesma forma que sua instrumentalização pelo Poder Executivo Federal e sua legalização pelo Poder Legislativo.

A cartografia política brasileira que se desenhou com a introjeção da tese do marco temporal representa uma ameaça ao núcleo essencial de direitos indígenas, bem como à sustentabilidade socioambiental e consolidação do Estado Democrático de Direito, sob o prisma do respeito à diversidade cultural. À guisa de uma possível conclusão, cumpre enfatizar que o núcleo essencial de direitos, por comportar direitos com status constitucional, deve ser concretizado pelos poderes constituídos e ganhar corpo na sociedade brasileira. A preservação desses direitos não é, portanto, interesse único e exclusivo dos povos indígenas, mas é uma questão atinente ao povo brasileiro, é uma questão atinente à democracia, à proteção do patrimônio cultural, à preservação do meio ambiente, é uma questão atinente à humanidade.

\section{REFERÊNCIAS}

ACKERMAN, Bruce. The rise of the world constitutionalism. Virginia Law Review 83, n. 4, 1997. 
ISSN 1981-3694

(DOI): $10.5902 / 1981369439249$

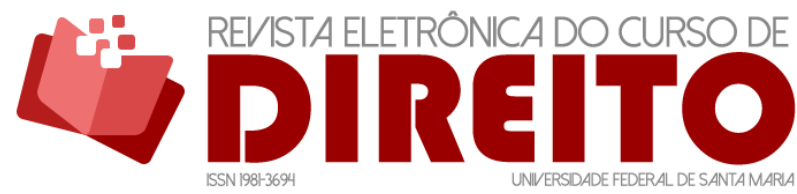

DIREITOS DE POVOS INDÍGENAS NO BRASIL: O “NÚCLEO ESSENCIAL DE DIREITOS" ENTRE DIVERSIDADE E INTEGRACIONISMO

MILENA PETTERS MELO THIAGO RAFAEL BURCKHART

ADVOCACIA-GERAL DA UNIÃO. Parecer n. 001/2017/GAB/CGU/AGU, Interessado: Casa Civil da Presidência da República. Diário Oficial da União, 19 jul 2017. Disponível em:

https://www.conjur.com.br/dl/parecer-agu-raposa-serra-sol.pdf. Acesso em: 23 ago. 2020.

ANAYA, S. James. Los pueblos indígenas en el derecho internacional. Trad. Luis RodríguezPiñero Royo. Madrid: Editorial Trotta, 2005.

ARATO, Andrew; COHEN, Jean; BUSEKIST, Astrid von. Forms of pluralism and democratic constitutionalism. New York: Columbia University Press, 2018.

BARBOSA, Marco Antônio. Autodeterminação: direito à diferença. São Paulo: Plêiade, 2011.

BARBOSA, Marco Antonio. Direito antropológico e terras indígenas no Brasil. São Paulo : Plêiade, 2001.

BENHABIB, Seyla. Las reivindicaciones de la cultura: igualdad y diversidade en la era global. Traducido por Alejandra Vassallo. Buenos Aires: Katz, 2006.

BHABHA, Homi. Nuevas minorias, nuevos derechos: notas sobre cosmopolitismos vernáculos. Buenos Aires: Siglo XXI, 2013.

BRASIL. Comissão Nacional da Verdade (CNV). Relatório. Brasília, 2014. . Disponível em: http://cnv.memoriasreveladas.gov.br/. Acesso em: 23 ago. 2020.

BOBBIO, Norberto. A era dos direitos. Rio de Janeiro: Elsevier, 2004.

BOURDIEU, Pierre. O poder simbólico. Lisboa: Difel, 1989.

CANOTILHO, José Joaquim Gomes. Direito Constitucional e Teoria da Constituição. Coimbra: Almedina, 2012.

COMITÊ ESTADUAL DA VERDADE DO AMAZONAS. 0 genocídio do Povo Waimir-Atroari. Manaus, 2012. Disponível em:

http://www.dhnet.org.br/verdade/resistencia/a_pdf/r_cv_am_waimiri_atroari.pdf. Acesso em: 23 ago. 2020

CUNHA, Manuela Carneiro da. Índios do Brasil: história, direitos e cidadania. São Paulo: Claro Enigma, 2012.

CUNHA, Manuela Carneiro da. Cultura com aspas e outros ensaios. São Paulo: Cosac Naufy, 2009.

CUNHA, Manuela Carneiro da. Índios na Constituição. Novos Estudos. CEBRAP, v. 37, p. 429-443, 2018.

CUNHA, Manuela Carneiro da; BARBOSA, Samuel (Orgs.). Direitos indígenas em disputa. São Paulo: Unesp, 2018.

DULCE, Maria José Fariñas. Democracia y pluralismo: una mirada hacia la emancipación. Madrid: Dykinson, 2014. 
FERNANDES, Pádua. Povos indígenas, segurança nacional e a Assembleia Nacional Constituinte. Revista Insurgência, Brasília, v. 1, n. 2, 2015.

FAJARDO, Raquel. Aos 20 anos da Convenção 169 da OIT: balanço e desafios da implementação dos direitos dos povos indígenas na América Latina. In: VERDUM, Ricardo (Orgs.). Povos indígenas: constituições e reformas políticas na América Latina. Brasília; Instituto de Estudos Socioeconômicos, 2009.

FERRAJOLLI, Luigi. Por uma teoria do direito e dos bens fundamentais. Porto Alegre: Livraria do Advogado, 2011.

FRIEDMANN, John . Empowerment. The Politics of Alternative Development. Oxford: Blackwell, 1992.

GILBERT, Jérémie. Direito à terra como direito humano: argumentos em prol de um direito específico à terra. Revista Internacional de Direitos Humanos, ed. 18, 2013.

GRIMM, Dieter. Constitutionalism: past, presente, future. Oxford: Orford University Press, 2016.

HALL, Stuart. A identidade cultural na pós-modernidade. Rio de Janeiro: D\&P, 2010.

HONNETH, Axel. Luta por reconhecimento: a gramática moral dos conflitos sociais. São Paulo: 34, 2003.

KAYSER, Hartmut-Emanuel. Os direitos dos povos indígenas do Brasil: desenvolvimento histórico e estágio atual. Porto Alegre: Sérgio Antonio Fabris, 2010.

LARAIA, Roque de Barros. Cultura: um conceito antropológico. Rio de Janeiro: Jorge Zahar, 2001.

MAZZUOLI, Valerio de Oliveira. Curso de Direito Internacional Público. 12. ed. Rio de Janeiro: Forense, 2018

MELO, Milena Petters. Entre Igualdade e Diversidade: Globalização, Migrações, Direitos Humanos e Relações Interculturais. In: PRONER, Caroline; BARBOZA, Estefania Maria de Queiroz; GODOY, Gabriel Gualiano de (org.) Migrações, Políticas e Direitos Humanos sob as perspectivas do Brasil, Itália e Espanha. Curitiba: Juruá, 2015.

PETTERS, Milena. O Patrimônio Comum do Constitucionalismo Contemporâneo e a virada biocêntrica do "Novo" Constitucionalismo Latino-Americano. Revista Novos Estudos Jurídicos, UNIVALI, v. 18, n. 1, 2013.

MINISTERIO PUBLICO FEDERAL. Nota Técnica n. $1 / 2020 / 6^{a}$ CCR/MPF, Procuradoria Geral da República, 2020. Disponível em: http://www.mpf.mp.br/pgr/documentos/document11.pdf. Acesso em: 23 ago. 2020.

MIRAS, Julia Trujillo (Org.). Makunaíma Grita! Terra indígena Raposa Serra do Sol e os direitos constitucionais no Brasil. Rio de Janeiro: Beco do Azougue, 2009. 
ISSN 1981-3694

(DOI): 10.5902/1981369439249

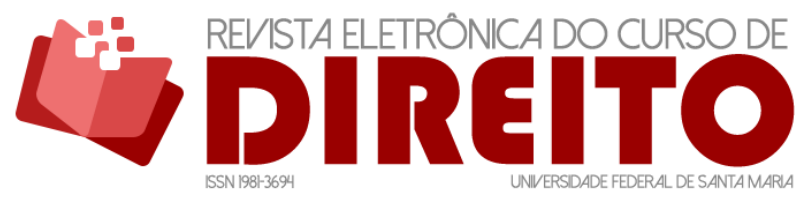

DIREITOS DE POVOS INDÍGENAS NO BRASIL: O “NÚCLEO ESSENCIAL DE DIREITOS" ENTRE DIVERSIDADE E INTEGRACIONISMO

MILENA PETTERS MELO THIAGO RAFAEL BURCKHART

NIEZEN, Ronald. The origins of indigenism: human rights and the politics of identity. Berkeley: University of California Press, 2003.

NIEZEN, Ronald. Public Justice and the Anthropology of Law. Cambridge: Cambridge University Press, 2010.

ONIDA, Valerio. La costituzione ieri e oggi. Bologna: Il Mulino, 2008.

POLANCO, Héctor-Dias. Elogío a la diversidad: globalización, multiculturalismo y etnofagía. México: Siglo XXI, 2006.

RAMOS, Alcida Rita. Indigenism: ethnic politics in Brazil. Madinson: University of Wisconsin Press, 1998.

ROUSSEAU, Dominique. Le droit constitutionnel continue : institutions, garantie des droits et utopie. Revue de droit publique et de la science politique en France e à l'étranger, v 130, 6, 2014.

SANTOS, Boaventura de Sousa; MENESES, Maria Paula. (Orgs.). Epistemologias do Sul. São. Paulo: Editora Cortez. 2010.

SÃO PAULO. COMISSÃO DA VERDADE DO ESTADO DE SÃO PAULO “RUBENS PAIVA”. Relatório. Capítulo Violações aos direitos dos povos indígenas. 2015.

SOUZA FILHO, Carlos Frederico Marés de. Multiculturalismo e direitos indígenas. In: SANTOS, Boaventura de Sousa (Org.). Reconhecer para libertar: os caminhos do cosmopolitismo cultural. Rio de Janeiro: Civilização Brasileira, 2003.

SOUZA FILHO, Carlos Frederico Marés. 0 renascer dos povos indígenas para o direito. Curitiba: Juruá, 1998.

STAVENHAGEN, Rodolfo. Etnodesenvolvimento: uma dimensão ignorada no pensamento desenvolvimentista. Anuário Antropológico, vol 84, 1985.

STAVENHAGEN, Rodolfo. Los pueblos originários: el debate necesario. Buenos Aires: CLACSO, 2010.

SUPREMO TRIBUNAL FEDERAL. Petição 3.388/RR, julgamento 19/03/2009, Relator: Min. Carlos Britto, Órgão Julgador: Tribunal Pleno. Disponível em:

http: //redir.stf.jus.br/paginadorpub/paginador.jsp?docTP=AC\&docID=630133. Acesso em: 23 ago. 2020

SUPREMO TRIBUNAL FEDERAL. Recurso Extraordinário n. 1.017.365, Relator: Edson Fachin, 2020. Disponível em:

http: / /www.stf.jus.br/portal/processo/verProcessoDetalhe. asp?incidente=5109720. Acesso em: 23 ago. 2020.

TOURAINE, Alain. Un nouveau paradigme pour comprendre le monde d'aujourd'hui. Paris: Fayard, 2005. 
TULLY, James. Strange multiplicity: constitutionalism in the age of diversity. New York: Cambridge University Press, 1995.

YAMADA, Erica Magami; VILLARES, Luiz Fernando. Julgamento da Terra Indígena Raposa Serra do Sol: todo dia era dia de índio. Revista Direito GV, 2010, vol.6, n.1, pp.145-157.

YASH, Ghai. Constitutionalism and the challeng of ethnic diversity. World Justice Forum, Viena, 2008.

ZIZEK, Slavoj. In defense of lost causes. New York: Verso, 2008.

\section{COMO FAZER REFERÊNCIA AO ARTIGO (ABNT):}

PETTERS MELO, Milena, BURCKHART, Thiago Rafael. DIREITOS DE POVOS INDÍGENAS NO BRASIL: O "NÚCLEO ESSENCIAL DE DIREITOS" ENTRE DIVERSIDADE E INTEGRACIONISMO. Revista Eletrônica do Curso de Direito da UFSM, Santa Maria, RS, v. 15, n. 2, e39249, maio./ago. 2020. ISSN 1981-3694. DOI: http://dx.doi.org/10.5902/1981369439249. Disponível em:

https://periodicos.ufsm.br/revistadireito/article/view/39249. Acesso em: dia mês. ano.

Direitos autorais 2020 Revista Eletrônica do Curso de Direito da UFSM

Editores responsáveis: Rafael Santos de Oliveira e Angela Araujo da Silveira Espindola

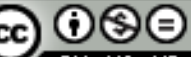

Esta obra está licenciada com uma Licença Creative Commons Atribuição-NãoComercial-SemDerivações 4.0 Internacional.

\section{SOBRE OS AUTORES}

\section{MILENA PETTERS MELO}

Possui graduação em Direito, UFSC (Brasil,1999); Formação em Direitos Humanos junto ao Instituto Interamericano de Derechos Humanos, IIDH (Costa Rica, 2001); Doutorado em Direito, Università degli Studi di Lecce, UNISALENTO (Itália, 2004); Formação em Cooperação Descentralizada e Diplomacia no Novo Atlante da Solidariedade Internacional Universidade Internacional das Instituições e dos Povos para a Paz, UNIP (Itália, 2005). Atualmente é Professora Titular de Direito Constitucional e Direito Humanos e Sustentabilidade, Universidade Regional de Blumenau FURB. Professora do Mestrado em Direito Público e Constitucionalismo da FURB. Coordenadora do Núcleo de Estudos em Constitucionalismo Contemporâneo, Internacionalização e Cooperação CONSTINTER, FURB. Professora e Coordenadora para a área lusófona do Centro EuroAmericano sobre Políticas Constitucionais CEDEUAM, UNISALENTO, Itália. Coordenadora da sede Brasileira do CEDEUAM, FURB, Brasil. Professora e membro do Conselho Científico do Doutorado em Direito Comparado e Processos de Integração da Universidade da Campania Luigiigi Vanvitelli - UNICAMPANIA, Itália.Professora Associada à Academia Brasileira de Direito Constitucional ? ABDConst. Professora do Programa de Doutorado em Ciências Jurídicas e Políticas, Universidade Pablo de Olavide ? UPO, Espanha. Pesquisadora do Institut International d?Etudes et Recherches sur les Biens Communs (Instituto Internacional de Estudos e Pesquisa sobre os BensComuns) IIERBC, França/Itália. Parecerista do Conselho Nacional de Pesquisa e Pós-Graduação em Direito CONPEDI e do Conselho Internacional de Estudos Contemporâneos em Pós-Graduação CONSINTER. Consultora em projetos de internacionalização, intercâmbio de good practices e cooperação acadêmica, cultural e científica entre a Europa e a América Latina. Tem experiência na área de Direito, com ênfase em Direito Constitucional e Direito Internacional Público, atuando principalmente nas seguintes temáticas e segmentos disciplinares: Direito Constitucional Internacional, Direito Constitucional Ambiental, direitos fundamentais, políticas constitucionais, direitos 
ISSN 1981-3694

(DOI): $10.5902 / 1981369439249$

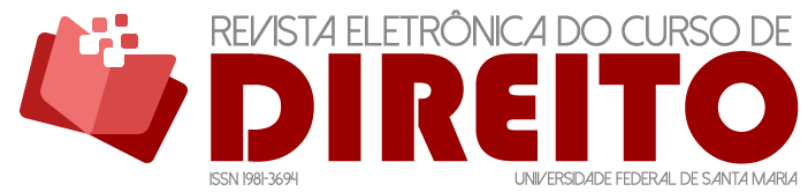

DIREITOS DE POVOS INDÍGENAS NO BRASIL: O “NÚCLEO ESSENCIAL DE DIREITOS” ENTRE DIVERSIDADE E INTEGRACIONISMO

MILENA PETTERS MELO THIAGO RAFAEL BURCKHART

humanos, sustentabilidade socioambiental, justiça ecológica e mudanças climáticas, estudos para a paz, proteção do patrimônio cultural e relações interculturais, comparação constitucional com a Europa, América do Sul e Comunidade Lusófona. Foi Coordenadora Local do Doutorado Interinstitucional em Direito DINTER FURB/UNISINOS (2015-2018), Coordenadora da Revista Jurídica da FURB (2012-2018), Coordenadora do Grupo de Estudos da ABDConst na FURB: O patrimônio comum do constitucionalismo democrático e a contribuição da América Latina, de 2012 a 2018. Professora associada e colunista da Escola Superior de Direito Público - ESDP (2016-2018). Foi consultora da Associazione Studi Giuridici per le Migrazione (Itália, 2008-2012). Pesquisadora do Centro di Ricerca sulle Istituzioni Europee - CRIE (UNISOB, Itália 20062010), FORMAMBIENTE/FORMEZ (Itália, 2004-2008) do Istituto Italiano per gli Studi Filosofici (Italia, 2002-2003), Rete Tematica Immaginare l?Europa (Italia 1998-2007), Rete SOCRATE una Filosofia per IEuropa (2001-2003), Institut fur Rechts und Sozialphilosophie - Universitat des Saarlandes Saarbrucken (Alemanha 1999-2001).

\section{THIAGO RAFAEL BURCKHART}

Doutorando em Direito Público Comparado pela Università degli Studi della Campania Luigi Vanvitelli (Itália). Possui mestrado em Direito pela Universidade Federal de Santa Catarina (2019) e graduação em Direito pela Universidade Regional de Blumenau (2016). Pesquisador do Centro Euroamericano sulle Politiche Costituzionali (Università del Salento, Itália/Brasil). Pesquisador do Núcleo de Estudos em Constitucionalismo, Internacionalização e Cooperação, Constinter/Furb. Possui os seguintes livros publicados: "O que são os Direitos Humanos?" (Prismas, 2016); "Constitucionalismo na América Latina: a refundação do Estado e as epistemologias do sul" (Prismas, 2016); "Direito, Cultura e Cidadania" (Prismas, 2017); "Constitucionalismo, direitos humanos e sustentabilidade socioambiental" (Imaginar o Brasil, 2020, no prelo); "Constituição, direitos de povos indígenas e o caso Raposa Serra do Sol" (Imaginar o Brasil, 2020, no prelo). Realizou a tradução da obra "Democracia y Pluralismo" da Profa. Dra. Maria Jose Farinas Dulce (2019, Tirant Lo Blanch). Membro da Rede Internacional para o Constitucionalismo Democratico Latino-Americano. Tem trabalhado e publicado nos campos do Direito Constitucional e Direito Internacional Público, dedicando-se aos seguintes temas: direito constitucional internacional, direito constitucional ambiental, direito constitucional comparado, direitos fundamentais, constitucionalismo democrático, direitos culturais e proteção do patrimônio cultural, direitos de povos indígenas e sustentabilidade socioambiental, cidadania e direito internacional dos direitos humanos. 